Portland State University

PDXScholar

7-9-1997

\title{
Lewis and Clark at Fort Clatsop: A winter of Environmental Discomfort and Cultural Misunderstandings
}

Kirk Alan Garrison

Portland State University

Follow this and additional works at: https://pdxscholar.library.pdx.edu/open_access_etds

Part of the Diplomatic History Commons, and the United States History Commons Let us know how access to this document benefits you.

\section{Recommended Citation}

Garrison, Kirk Alan, "Lewis and Clark at Fort Clatsop: A winter of Environmental Discomfort and Cultural Misunderstandings" (1997). Dissertations and Theses. Paper 5394.

https://doi.org/10.15760/etd.7267

This Thesis is brought to you for free and open access. It has been accepted for inclusion in Dissertations and Theses by an authorized administrator of PDXScholar. Please contact us if we can make this document more accessible: pdxscholar@pdx.edu. 


\section{THESIS APPROVAL}

The abstract and thesis of Kirk Alan Garrison for the Master of Arts in History were presented July 9,1997 , and accepted by the thesis committee and the department.

COMMITTEE APPROVALS:

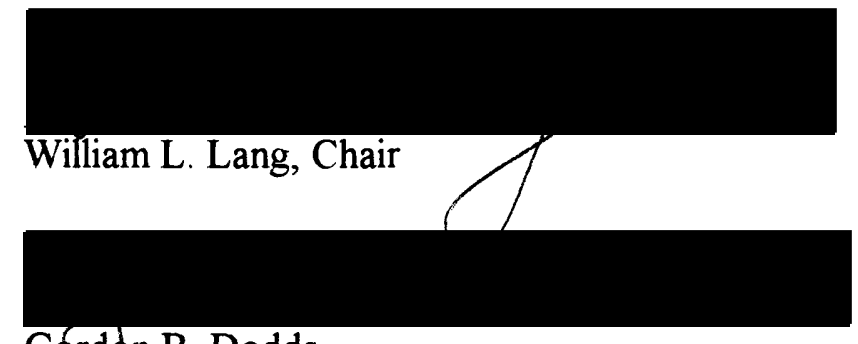

Gordon B. Dodds

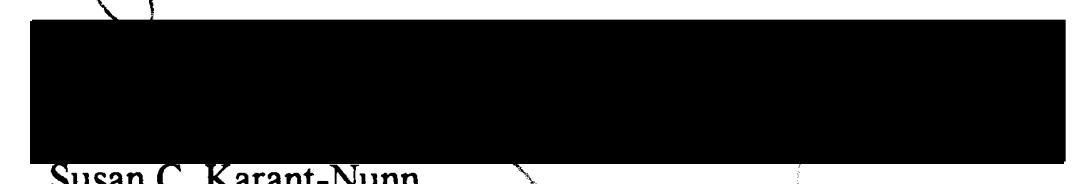

Susan C. Karant-Nunn

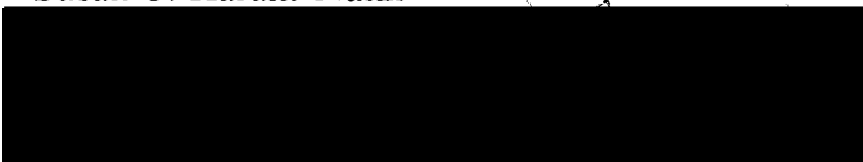

Mafia Wilson-Figueroa

Representative of the Office of Graduate Studies

DEPARTMENT APPROVAL:

Gofdon B. Dodds, Chair

Department of History

$* * * * * * * * * * * * * * * * * * * * * * * * * * * * * * * * * * * * * * * * * * * * * * * * * * * * * * * * * * * * * * * * * * * * *$

ACCEPTED FOR PORTLAND STATE UNIVERSITY BY THE LIBRARY

by

on

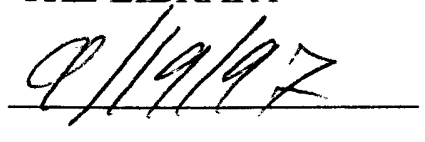




\begin{abstract}
An abstract of the thesis of Kirk Alan Garrison for the Master of Arts in History, presented 9 July 1997.
\end{abstract}

Title: Lewis and Clark at Fort Clatsop: A Winter of Environmental Discomfort and Cultural Misunderstandings

Members of the Lewis and Clark expedition did not like the 1805-1806 winter they spent at Fort Clatsop near the mouth of the Columbia River among the Lower Chinookan Indians, for two reasons. First, the environment west of the Rocky Mountains was unlike anything they had ever experienced or imagined, and it had such a powerful effect on the whites as to negatively influence their attitudes regarding the western landscape, and to prejudice the explorers against the peoples living in that environment.

Second, the cultures of the Lower Chinook Indians and the whites were so different that often neither group comprehended the motives and actions of the other, resulting in mutual resentment and dislike. Lewis and Clark often portray these Indians as thieves, price-gouging traders, and physically unattractive, but an examination of Chinookan culture gives another viewpoint: the Indians felt they were acting in 
legitimate and reasonable ways, and that it was the white visitors who were strange and unpredictable

To comprehend Lower Chinookan culture I rely on the records left by the earliest visitors to the Columbia River (mainly fur traders), as well as more recent anthropological studies of those Indians. For an understanding of expedition attitudes, I depend mainly on The Journals of the Lewis \& Clark Expedition, eleven volumes of expedition writing edited by Gary Moulton. A close examination of these party journals reveals two related trends. In the early part of their stay, expedition members often complain about the environment on the lower Columbia, but these protests gradually die out early in 1806. But, conversely, complaints about the Lower Chinookan Indians gradually grow stronger, continuing even after the expedition has left the coast. This suggests that the explorers gradually shifted their complaints away from what they could not control, the environment, to what they felt they could do something about, the Indians living in that environment. All of these attitudes and opinions resulted in a disagreeable winter for the explorers, and probably for the Chinook Indians as well. 
LEWIS AND CLARK AT FORT CLATSOP:

A WINTER OF ENVIRONMENTAL DISCOMFORT

AND CULTURAL MISUNDERSTANDINGS

by

KIRK ALAN GARRISON

A thesis submitted in partial fulfillment of the

requirements for the degree of

\section{MASTER OF ARTS \\ in \\ HISTORY}

Portland State University

1997 


\section{Chapter}

\section{TABLE OF CONTENTS}

1. INTRODUCTION

- The Lewis and Clark Expedition

- The Journal-Keeping Methods of Lewis and Clark

- The Lower Chinook

- Traders and Explorers: Other Sources

\section{PART I: THE EXPLORERS AND THE ENVIRONMENT ON THE LOWER COLUMBIA}

2. A DIFFERENCE OF ENVIRONMENT

- Fleas and Other Bothersome Creatures

- The Orerpowering Elements

PART II: THE EXPLORERS AND

THE INDIANS ON THE LOWER COLUMBIA

3. STEALING, OR NEGATIVE RECIPROCITY.

- Stealing: Social Distance and Simple Greed

- Stealing to Recoup Losses

- Stealing and Harassment in Lieu of Gifts

4. BALANCED RECIPROCITY

- Clark and Cus-ka-lah

- The Captains and Shâh-hâr-wâr-cap

- Comowool. the Captains Favorite

- Tâh-cun and Lewis Diatribe

5. THE LOWER COLUMBIA MARKET SOCIETY

- The Expedition. the Chinook, and the Canoe: Different Conceptions of Trade

6. CHINOOKAN CUSTOMS AND APPEARANCE

- Tattooing and Ankle Binding

- Head Deformation

- General Chinookan Appearance

7. CONCLUSION 


\section{CHAPTER 1}

\section{INTRODUCTION}

The Lewis and Clark Expedition met with and described many different groups of Indians on their journey to the Pacific. After all, that was one of the purposes of their trip, since President Thomas Jefferson had instructed Lewis that "the commerce which may be carried on with the people inhabiting the line you will pursue [i.e., the Indians in the West], renders a knolege [sic] of these people important." Both captains did observe and record much about the various tribes they encountered, but their meetings were usually so brief it is hard to tell how expedition members really felt about these Native Americans, with two exceptions. The party first spent considerable time with the Mandans, whom they wintered among in present day North Dakota from November of 1804 to early April of 1805, and as a result, the explorers left extensive records detailing their interaction with these Missouri tribes. The second group of Indians Lewis and Clark spent a good deal of time among were the various Chinookan tribes on the Pacific Coast, where the party stayed for about four and one half months the following winter, and here we also have much written about contacts between these Indians and the white explorers.

\footnotetext{
Jefferson's instructions to Meriwether Lewis. written 20 June 1803. Printed in David Lavender. The II ay to the IVestern Sea: Lewis and Clark Across the Continent (New York: Anchor Books. 1988). 390 .
} 
Expedition members thought highly of the Mandans, frequently hunting with and visiting them, and the Indians, in turn, were regular guests at Fort Mandan. Lewis even became good friends with "the black-Cat the principal chief of the Roop-tar-he, or upper Mandane Vilage." He writes "this man possesses more integrety, firmness, inteligence or perspicuety of mind than any indian I have met with in this quarter. . ."2 But the party did not feel the same way about the Chinook Indians, and the time they spent on the Pacific Coast. James Ronda notes the contrast between "the excitement and anticipation that had run through life ... at Fort Mandan" and "the predictable procession of wind, storm, and fog" as well as "mildew, spoiled meat, and numbing boredom" that "a season at Fort Clatsop seemed to promise." Party members enjoyed their visits with the Mandans, but they did not like their time among the Chinooks.

In this work I will look at why this is so. Specifically, I will show that there are two reasons the white explorers disliked the winter they spent with the West Coast Indians. First, the environment was unlike anything they had ever experienced or even imagined. As William Lang has argued regarding this subject, "an inherent power in the western landscape was among the most important factors in the Lewis and Clark expedition," and "how the leaders reacted to the environment significantly influenced their perceptions of people and place. ..." As we will see, Lewis and Clark often reacted negatively to the Northwest environment and, by extension, the coastal Indians.

\footnotetext{
2 Gary E. Moulton. editor. The Journals of the Levis \& Clark Expedition, 11 volumes (Lincoln. Nebraska: University of Nebraska Press, 1990), 3:289.

${ }^{3}$ James Ronda. Lewis and Clark Among the Indians (Lincoln. Nebraska: University of Nebraska Press. 1984). 181
} 
Second, members of the Lewis and Clark Expedition did not enjoy their time on the Pacific Coast because of cultural misunderstandings with the Indians they stayed among, the Lower Chinook. The captains' journals portray these natives as habitual thieves, price gouging traders, and squat, ugly, and dirty in appearance, and these characterizations became more and more negative throughout the winter.

But in such a situation where two cultures come together, "the experience of the indigenous society is as significant as the experience of the intrusive one," careful examination of Lower Chinookan culture, and a closer look at the explorers' entries, gives another side to this story. Often, when the whites felt the natives were stealing from them and taking advantage of their need for supplies, the Chinook were doing nothing of the kind, but the two cultures were so different that neither group comprehended the motives of the other. To expedition members, it made more sense to consider the Lower Chinook Indians habitual thieves and avaricious traders than to believe that in the Chinookan culture, their actions were justifiable. In short, the combination of being in a "strange," or "unknown," environment, and living among people who, in their eyes, acted in unpredictable and inexplicable ways, led to a very disagreeable winter for the whites, as we will see. But before getting into an analysis of the expedition experience throughout the Fort Clatsop winter, I need to briefly describe the entire expedition, discuss the journal keeping methods of its members, supply some

\footnotetext{
${ }^{4}$ William L. Lang. "Lewis and Clark on the Columbia River: The Power of Landscape in the Exploration Experience." Pacific . .orthwest Quarterly 87 (Summer 1996): 141.

${ }^{5}$ Howard Lamar and Leonard Thompson. editors. The Frontier in History: North America and South Africa Compared (New Haven: Yale University Press. 1981). 4.
} 
background material on the Lower Chinook, and review some of the sources outside the expedition journals.

\section{The Lewis and Clark Expedition}

Though we often speak of the Lewis and Clark expedition as a single entity, it is important to remember that the people who constituted it were not a homogeneous group. The thirty-one men who were with the party during the Fort Clatsop winter included Americans of various backgrounds, French-Canadians, and Clark's slave York. In addition, the Shoshone Indian woman Sacagawea and her infant son Jean Baptiste made the journey to the Pacific Coast. ${ }^{6}$ A group as diverse as this obviously had many different attitudes and prejudices, but since few of the party members kept journals, we really do not know much about the experiences and feelings of most of them. And those who did write generally did not record anything beyond a mere catalogue of events. Even the two members who wrote the most, Lewis and Clark, are careful in their writings to hide what they are feeling during this journey, as well as their prejudices toward the Indians they come into contact with. Despite this, the captains do occasionally let their thoughts, feelings, and biases, show, and these instances can illustrate how they felt about the Lower Chinook, and about Native Americans in general.

The expedition that headed up the Missouri River in May of 1804 was not the result of any sudden impulse. Thomas Jefferson had attempted to launch such an exploring party as early as 1783 , and by the time he became president in 1801 he had sponsored 
or promoted three other attempts. But the expedition he planned and sent out under Meriwether Lewis had three advantages over the earlier attempts. First of all, the geography of western North America was much better known. In 1792, the American fur trader Robert Gray discovered the Columbia River, ${ }^{7}$ and later that year the British explorer Captain George Vancouver sent one of his officers, Lieutenant William Broughton, about one hundred miles up the new river. Vancouver also explored and mapped much of the Northwest Coast, and his findings (including Broughton's) were published in $1798,{ }^{8}$ and Lewis purchased and read this work before he began his journey. ${ }^{9}$ Second, Jefferson was president, and so, writes Gary Moulton, "was in a better position to launch such an expedition and to assure adequate financing.,"10 And third, the 1803 Louisiana Purchase meant that the explorers would be legitimately traveling through United States territory, though it is important to recognize that Lewis was already heading west when the transaction was completed. ${ }^{11}$

Lewis began his travels in the summer of 1803 , when he journeyed to Pittsburgh and picked up a keelboat and some of his men. They floated down the Ohio River in August of that year, joined Clark and more recruits at Clarksville, Indiana, and

\footnotetext{
${ }^{6}$ For brief biographies of each expedition member, see Moulton, Journals. 2: 509-29.

I mean discovered $b$. whites. of course. Indians had been living on the Columbia River for thousands of years.

${ }^{8}$ For Gray"s discovery of the Columbia. see F. W. Howay. Ioyages of the "Columbia" to the lorthuest Coast, 1787-1790 and 1790-1793 (Boston: The Massachusetts Historical Societr. 1941): 396-99. 436-38; for Vancouver's survey, and Broughton's report. see George Vancouver, A l'oyage of Discovery to the North Pacific Ocean and Round the World 1791-1795. edited by W. Kaye Lamb. volume 2 (London: The Hakluyt Society, 1984), 747-70.

${ }^{9}$ Donald Jackson. editor. Letters of the Lewis and Clark Expedition, With Related Documents 17831854 (Chicago: University of Chicago Press, 1978). 1: 13n. 53.

${ }^{16}$ Moulton. Journals. 2:2.

"1) ibid.. 3.
} 
continued to St. Louis, Missouri. The expedition spent the winter of 1803-1804 at Camp Dubois, on the Wood River a few miles up the Missouri from St. Louis. On 14 May 1804 they embarked on their journey up the Missouri River, and arrived at their winter campsite in present-day North Dakota about 13 November 1804, where they built Fort Mandan. They departed from this fort on 7 April 1805, reaching the Continental Divide at today's Idaho/Montana border on 12 August of that year. They had hoped to portage across the divide to the headwaters of a westward flowing stream and simply float down it to the Columbia, but they soon realized the western geography would not allow such an easy trip. Instead, they cached their canoes, borrowed and purchased horses from the friendly Shoshone Indians, and headed west, guided by one of their new native acquaintances.

After a difficult journey on horses through the Bitterroot Range of the Rocky Mountains, on 26 September 1805 the party arrived among the Nez Perce Indians living on the Clearwater River. Here they built new canoes, and beginning 7 October, floated in turn down the Clearwater, the Snake, and the Columbia rivers, reaching the coast in early November. After spending the winter that will be the focus of this work at Fort Clatsop, the party began their return journey on 23 March 1806, and (with a few deviations) retraced their path. They crossed back over to the eastern side of the Continental Divide in June, passed Fort Mandan in the middle of August, and finally reached St. Louis 23 September 1806, where they were welcomed by amazed citizens who had long given them up for dead. ${ }^{12}$ 


\section{The Journal-keeping Methods of Lewis and Clark}

The journals of this expedition are more complicated than one would expect. The total expedition writings cover the period from 30 August 1803 to 23 September 1806 , and include journals from six men: Lewis; Captain William Clark; ${ }^{13}$ Sergeants John Ordway, Patrick Gass, and Charles Floyd; and Private Joseph Whitehouse. And while these diverse sources enrich our understanding of the journey, they also give us that much more material to comprehend. The issue is further clouded by gaps in Lewis' journal writing that extend for months at a time, as well as the existence of, at times, two entries each day written by Clark. ${ }^{14}$ I do not want to get into a comprehensive discussion of every expedition codex here, but it is necessary to understand how the documents recording the Fort Clatsop winter were produced.

As the expedition first came into contact with the Lower Chinook Indians in November and December of 1805 , Lewis only wrote on three days that we know of: the $29^{\text {th }}$ and $30^{\text {th }}$ of November, and the $1^{\text {st }}$ of December. These entries are known as Codex la, and do not appear to be part of a larger unknown work, but seem to stand alone ${ }^{15}$ Lewis resumed his consistent journal entries in a notebook known as Codex $\mathrm{J}$, which begins 1 January 1806 and ends 20 March 1806. Codex K, covering from 21

\footnotetext{
${ }^{13}$ When Lewis asked Clark to join him on the expedition. he assumed his friend would be given the same rank he held -captain-"but," writes Moulton, "red tape in the Department of War resulted in Clark's receiving only a second lieutenant's commission." But both kept this fact secret, and Lewis always refers to his friend as "Capt. Clark" in the journals. so it is customary for historians to consider both leaders captains. I will continue this tradition. See Moulton. Journals. 2: 6.

${ }^{14}$ There is some speculation that Lewis did write regularly. but his journals have been lost. For a detailed discussion on this. as well as the other codices. see Moulton. Journals, 2:8-42.

${ }^{15}$ ibid. 22-3.
} 
March to 23 May 1806, contains the balance of Lewis' known writings from this period

Clark's writings from this period are more complicated. Up through 3 January 1806 there are two entries for each day, with each set recorded in different notebooks. The first set is contained in a book known as his "Elkskin-bound Journal," which covers the period from 11 September 1805 to 31 December 1805 . The entries in this journal for the period I am discussing are known as Clark's "Field Notes," because they seem brief and cryptic when compared to his second set of known writings, called his "Journal Entries." These are found in three notebooks known today as: (1)-Codex $\mathrm{H}$ (covering 11 October to 19 November 1805); (2)-Codex I (19 November 1805 to 29 January 1806); and (3)-Voorhis No. 2 (30 January to 3 April 1806)

The material in Codices $\mathrm{H}$ and I that covers the same dates as Clark's Elkskinbound Journal (up to 31 December 1805) seems to be a "second draft" of the "first draft" Field Notes, because entries are usually longer, have more detail, and contain more information. After 1 January 1806 Clark took his information for his Journal Entries from a different source-he copied Lewis' entries from the above-mentioned Codices $\mathrm{J}$ and $\mathrm{K}$ almost word for word, though he sometimes put the entries under different dates than Lewis had. Presumably, Clark was not keeping his own journal because he was busy compiling all of his maps of their journey across the Rocky Mountains into one, but at some point the captains decided that they would duplicate Lewis' journal in case it was lost or destroyed. So, in Codices H, I, and Voorhis No. 1, 
Clark first of all elaborated on his Field Notes from the Elkskin-bound Journal, and after the final entry in that Journal (on 31 December $1805^{16}$ ) Clark copied Lewis' writings. Historians call this second version of Clark's journal his Journal Entries.

It is important to understand these journal keeping methods because there is evidence that Clark wrote his Journal Entries much later than his Field Notes, at least four months and possibly six or seven, probably while "the expedition remained at Camp Chopunnish, in the Nez Perce Country of Idaho, waiting for the snow to melt in the Bitterroot Mountains . ..,"17 The most compelling evidence for this comes from Clark's Journal Entry for 7 November 1805, which

contains a passage in quotes describing the dress of the local Indian women, noting that it was so skimpy that the "battery of venus is not altogether impervious to the penetrating eye of the amorite." Not only is the language most unlike Clark's, but the whole paragraph is placed in quotation marks to indicate that it was not Clark's. In fact, the whole paragraph occurs verbatim in Lewis' Codex J [journal] entry for March 19, 1806-over four months after the ostensible date of Clark's entry. This forces us to conclude that Clark wrote the November 7,1805 , entry in Codex $\mathrm{H}$ on or after March 19, 1806. Lacking any indication that the page with the quoted paragraph was inserted later, we must assume that the remainder of Codex $\mathrm{H}$ after that date-and Clark's subsequent notebook journals, largely copied from Lewis-were written on or after March 19, 1806.

\footnotetext{
${ }^{16}$ I do not want to complicate this matter any further. but I should note that Clark apparently at first planned to continue his Field Note entries after December 31. The Elkskin-bound Journal was filled up. "But Clark's Codex I has three short entries for January 1, 2, and 3 at one end of the book upside down to all the rest of the writing in that book, which starts at the other end. It would seem that Clark began Codex I as a continuation of the Elkskin-bound Journal (ending December 31), then decided to do something else" (Moulton. Journals. 1: 26).

${ }^{1-}$ Thomas W. Dunlay, "'Battery of Venus': A Clue to the Journal-Keeping Methods of Lewis and Clark." He Proceeded On 9 (July 1983): 8. See also the section titled "The Journal-Keeping Methods of Lewis and Clark" in Moulton. Journals, 2: 8-48.

${ }^{18}$ ibid. 25.
} 
The fact that a direct quote from Lewis' journal that was not written until 19 March 1806 appears in Clark's 7 November 1805 Journal Entry forces us to conclude the Clark entry from November was written after 19 March 1806, as were his subsequent Journal Entries.

There are other evidences that Clark's Journal Entries were written later than his Field Notes. For example, in his Journal Entry for 30 November 1805 Clark describes the construction of Lower Chinookan burial scaffolds with detail that seems unusual for him. ${ }^{19}$ But the passage appears verbatim in Lewis' entry on 9 January $1806,{ }^{20}$ and since the style is most unlike Clark, but typical of Lewis' descriptive prose, we can conclude that Lewis was the author. Once again, a passage written by Lewis appears in one of Clark's journal entries under an earlier date (in this case, a month and a half earlier).

It is significant that Clark's Journal Entries were probably written after the expedition left the lower Columbia region because these later entries are often more negative toward the coastal Indians than his Field Notes, and this could mean one of two things. It could indicate that Clark was more candid in his later descriptions of the Lower Chinook; that he had always felt as negatively towards them as his Journal Entries indicate, but he concealed his true feelings when he composed his first draft Field Notes. Or, these prejudiced Journal Entries could indicate that the more time Clark spent among the Chinook, the more negative his attitude towards them became. The result, in either case, is the same: if Clark did not like the Chinook from the

\footnotetext{
19 ibid. 6: 97 .

20 ibid. 186.
} 
beginning, but hid these feelings when he composed his Field Notes, by the time the winter was over his dislike outweighed any pretense towards objectivity.

This facet of Clark's journal writing is illustrative of a trend in the journals I will examine in the body of this work. In chapter 2 , we will see that the captains' negative comments about the environment begin to taper off in early January 1806, and are nonexistent by February. Since there does not seem to have been a sudden change in the expedition's environmental situation, this raises a question: what happened to make the captains stop complaining about these issues? The difference between Clark's Field Notes and Journal Entries supplies a possible answer. When we recognize that comments critical towards environmental conditions in the journals are common in the first part of the Fort Clatsop winter but then fade away, and that, conversely, derogatory comments regarding the Lower Chinook are less common in the early part of the explorers' stay on the coast, but become more frequent and negative as the winter progresses, we can recognize a pattern. The captains seem to be transferring their criticism from the environment to the Indians who live in that environment. And the fact that Clark's biased Journal Entry comments are always directed towards these Indians, rather than the weather or anything else, seems to substantiate this view.

\section{The Lower Chinook}

The Lewis and Clark Expedition initially encountered Chinookan-speaking people in the Columbia River Gorge, when they met such tribes as the Wishram and Wasco around Celilo Falls and The Dalles Rapids. These tribes are part of the linguistic group 
known today as the "Upper Chinook." 21 As the party neared the mouth of the

Columbia, they met four groups of Chinook Indians:

The people on the north shore at the mouth of the river, whose territory extended northward along the Washington coast to Willapa (formerly Shoalwater) Bay, were known as the Chinook proper, Shoalwater Chinook, or Lower Band of Chinook. . . Opposite these people on the south shore at the mouth of the river and along the northern Oregon coast were the Clatsop. Above these two groups along the Columbia River were the Wahkiakum on the north bank and the Kathlamet on the south bank. ... All four Chinookan groups at the mouth of the Columbia River shared many aspects of their lifeways in common, and for this reason were considered together as the "Lower Chinook" in the principal account of these peoples by [Verne] Ray.... ${ }^{22}$

During their time on the lower Columbia, the Lewis and Clark expedition had extensive contact with the Chinook and the Clatsop, and considerable communication with the Wahkiakum and the Cathlamet groups of the Lower Chinook. Their journals reflect this interaction. But these Indians had also dealt with other whites before the expedition arrived at the mouth of the Columbia River in 1805, and some of these explorers and traders left us with records of their experiences on the lower Columbia

\section{Traders and Explorers: Other Sources}

On 11 May 1792, the American Captain Robert Gray of the Boston trading ship Columbia Rediviva sailed his vessel across the turbulent bar of a river on the Northwest coast at a latitude of approximately $46^{\circ} 7$ ', and named it "Columbia's

\footnotetext{
${ }^{21}$ For a good survey of Wasco and Wishram Indians. see David French. "Wasco-Wishram," chapter in Perspectives in American Indian Culture Change. edited by Edward H. Spicer (Chicago: University of Chicago Press. 1961). 337-430.

2 Rick Minor. "Aboriginal Settlement and Subsistence at the Mouth of the Columbia River" (Ph.D. Diss.. University of Oregon. 1983). 47. For the names of Indian groups and individuals. I have adopted the spelling used in Moulton's editorial apparatus. except where the names are spelled
} 
River," after his ship. ${ }^{23}$ Other trading vessels soon followed the Columbia into the newly discovered river, ${ }^{24}$ but the next white men who did so and left records were under Captain George Vancouver, who had command of a British squadron exploring the coast. He learned of the new river from Gray, and in early October 1792 his squadron, consisting of the Discovery, under the command of Vancouver, and the Chatham, commanded by Lieutenant William Broughton, arrived off the mouth of the river. The Discovery drew too much water to navigate the bar at the river's mouth, but the (hatham entered the estuary, and two longboats under Broughton's command explored up the Columbia for about one hundred miles (to the area of present-day Camas. Washington), leaving us a detailed record of their journey. ${ }^{25}$

The next whites to enter the river and leave an account were aboard the Mexicana, a Spanish exploring ship. Early in August of 1793, this ship entered the river and sailed up the north shore about fourteen miles, where it ran aground. After a skirmish with the Lower Chinook, the party left the river on 12 August. ${ }^{26}$ And although we know there were fur traders frequenting the river after this, the next extent journal from the

differently in quotations. Hence. in the quote here Minor writes "Kathlamet." but in my commentary below it I write "Cathlamet."

${ }^{23}$ Edmond S. Meany. editor, "New Log of the Columbia by John Boit." Washington Historical Quarterly 12 (January 1921): 32-34. Gray was not the first white man to suppose there was a river at this location. but was only the first to actually cross the bar. For a good summary of the process leading up to Gray's entrance into the Columbia River, see Thomas Vaughan, "River of the West." American History Illustrated 27 (May/June 1992): 28-43.

${ }^{24}$ See F. W. Howay, "Early Followers of Captain Gray," Washington Historical Quarterly 18 (January 1927): 11-20.

25 J. Neilson Barny. "Columbia River Exploration. 1792," Oregon Historical Quarterly 33 (March 1932): 36-42. 143-55: T. C. Elliott. "Log of Captain of H. M. S. Chatham," Oregon Historical Quarterly 18 (December 1917): 239-43: Vancouver. 747-70. For a list of the places visited by Broughton and their modern equivalents. see J. Neilson Barry. "Broughton on the Columbia in 1792." Oregon Historical Quarterly 27 (December 1926): 396-411. 
period was written 1795. In May of that year, Captain Charles Bishop of the British trading ship Ruby crossed the Columbia River bar and anchored in Baker Bay, just inside the north cape. He stayed for about a week, trading with the various Lower Chinookan tribes, and then sailed north for the summer. But on 18 October 1795 he returned to Baker Bay, where he stayed until late January of the following year. ${ }^{27}$

After Bishop, the next journal writers we know of to visit the lower Columbia were Lewis and Clark, during the winter of 1805-1806. And after these explorers, our next look at Chinookan life comes from a brief journal written by William Gale, an employee of the Winship brothers, who were from a Boston trading family. In 1809, these merchants attempted to establish a trading post about forty miles up the Columbia River, but were forced to leave by the Lower Chinook. ${ }^{28}$ Our next important records, and the last I will describe here, come from several of the Astorians, who established a trading post on the south shore near the mouth of the Columbia in 1811. Four of these men left written accounts of their time among the Lower Chinook: Robert Stuart, Alexander Ross, Ross Cox, and Gabriel Franchère.

I will use all of these sources, along with the work of several anthropologists, to help explain aspects of Lower Chinookan culture that members of the Lewis and Clark expedition did not understand. And while I recognize the danger of relying solely on the records of these white outsiders, who often exhibit prejudices in their descriptions

\footnotetext{
${ }^{26}$ Henry R. Wagner. "The Last Spanish Exploration of the Northwest Coast and the Attempt to Colonize Bodega Bay," California Historical Quarterly 10 (December 1931): 324-28.

$z^{-}$T. C. Elliott. "Journal of the Ship Ruby." Oregon Historical Quarterly 28 (September 1927): 25880
} 
of the Lower Chinook, there is no alternative: these are the only sources extent. Always remembering that virtually all the information we have regarding the early Lower Chinook comes to us through a filter of white bias and opinion can help counteract this problem. And although I do examine a wide range of sources, this work focuses on the attitudes and opinions of members of the Lewis and Clark expedition, so I will rely mainly on the writings left by the party members, of course. Quotations and extracts from this source make up the heart of each chapter in the body of this work, beginning with chapter two, on Lewis and Clark and the environment.

\footnotetext{
${ }^{28}$ Hubert Howe Bancroft. The Northwest Coast, 1800-1846. volume 28 of The Works of Hubert Howe Bancroft (San Francisco: The History Publishers, 1886). 129-35.
} 
PART I

\section{THE EXPLORERS AND THE ENVIRONMENT ON THE LOWER COLUMBIA}




\section{CHAPTER 2}

\section{A DIFFERENCE OF ENVIRONMENT}

When members of the Lewis and Clark Expedition crossed the Continental Divide from the Missouri River drainage into the Columbia River basin, they entered an environment unlike anything they had ever experienced or imagined. The captains had visualized a single row of peaks separating the two watersheds, but they soon discovered that the Rocky Mountains were "a complex series of ranges hundreds of miles wide." They had hoped to make a short portage across an easy pass to the headwaters of some stream that emptied into the Columbia River to the west, and then float down to the ocean, but they soon realized this was not possible.

The explorers had optimistically assumed the Columbia River and its tributaries would be similar to those of the Missouri, but they soon realized they were not. And though the negative environmental aspects of their western experience were, to an extent, balanced by the friendly Shoshone, Nez Perce, and Salish-speaking Indians, the whites were still not prepared "for the powerful effects the new landscape would have

\footnotetext{
'Moulton. Journals, 2: 5. The maps Jefferson and Lewis consulted and obtained generally showed the Rocky Mountains as a single chain, with the headwaters of the Columbia and Missouri "interlocking" on a high plateau. or through a gap, in those mountains. For the best discussion of this misconception. see John Logan Allen. Passage Through the Garden: Lewis and Clark and the Image of the American Yorthwest (Chicago: University of Illinois Press. 1975). 109-21. especially the King map. on pages 100 and 116 .
} 
on them and their expedition," according to Lang. ${ }^{2}$ The western landscape greatly influenced party members during their time on the coast and at Fort Clatsop. The strangeness of the new environment had a powerful enough effect on members of the expedition to negatively influence their attitudes toward the Indians living in those surroundings, particularly those expedition members spent the most time with-the Lower Chinook. And while I do not believe that the influence of environment was the only reason the white explorers did not like the Coastal Indians (as subsequent chapters will detail), I do feel this influence was significant. As Lang writes, "the environmental influences affected how the explorers interpreted places, human activity, and economic potential in the new landscape," and "also had a broader, even psychological effect on the leaders' decision making, their relationships with native peoples, and the general course of exploration.",

Before beginning my analysis of the Fort Clatsop winter, I need to set the stage. While I do not want to describe in detail the difficulties the party met with on the Lolo Trail as they crossed through the Rocky Mountains, nor record each dangerous rapid they encountered floating down the Clearwater, Snake, and Columbia rivers, I do need to discuss the attitudes and opinions of the members when they entered this unknown and unfamiliar world to the west A few passages, selected from expedition journals written during the Lolo Trail crossing and while the party was descending the Columbia River, will show how the explorers soon realized that this land west of the Rocky

\footnotetext{
"Lang. "Lewis and Clark." $1+1$.

ibid.
} 
Mountains was unlike anything they had imagined, and will indicate how they attempted to deal with this fact.

Meriwether Lewis, George Drouillard, and John Shields were the first expedition members to cross the Continental Divide, and while the latter two do not record the event, Lewis does. On 12 August 1805, he writes that as the three men climbed Lemhi Pass, they stopped to refresh themselves from the waters of the Missouri basin, and then "proceeded on to the top of the dividing ridge from which," Lewis records, "I discovered immence ranges of high mountains still to the West of us with their tops partially covered with snow." The three men then descended the western side of the pass to a "handsome bold running Creek of cold Clear water," and here, Lewis writes, "I first tasted the water of the great Columbia River." Although Lewis does not record his feelings, this first look to the west must have been disconcerting. When we remember his notions regarding a single range of mountains, with a simple portage from the headwaters of the of the Missouri to those of the Columbia, we can imagine what went through his mind. In the words of Allen, "The presence of the peaks of the Lemhi range must have come as a great shock, for no geographical lore extant provided for them.", But Lewis' journal is silent on this subject.

And the environment west of the Rocky Mountains continued to shock the explorers. They soon discovered the headwaters of the westward-flowing streams

\footnotetext{
${ }^{4}$ Moulton. Journals, 5: 74.

${ }^{5}$ Allen. Passage Through the Garden, 291. Allen notes another reason for Lewis to be uneasy here: how did he really know he had crossed the Continental Divide? The ranges of mountains to the west that still blocked his way could just have easily been the divide-he really didn 't know (Allen. Passage Through the Garden, 292: also see Lavender. Western Sea. 243).
} 
were not navigable, and were forced to purchase horses from the Shoshone Indians they met, hire a guide, and head off into those mountains they could see stretching to the west, on a portion of the journey Moulton calls "perhaps the severest test of the whole expedition." Clark describes a difficult journey as the expedition struggled through the Bitterroot Range of the Rocky Mountains along the present-day IdahoMontana border, but he rarely recounts his own misgivings regarding the situation the explorers found themselves in. However, on 15 September 1805-more than a month after Lewis first gazed on those seemingly endless mountains-he does give us a glimpse into what he was thinking. He describes an ascent up a "mountain Steep \& ruged as usial," and then writes with some unease "from this mountain I could observe high ruged mountains in every direction as far as I could See." Four days later Sergeant Ordway records a similar passage, writing "the Mountains continue as fer as our eyes could extend," and his next comment illustrates the expedition attitude at the time: "they extend much further than we expected," a classic understatement regarding the expedition's shattered beliefs about the western landscape ${ }^{8}$

While these entries do not explicitly tell us expedition attitudes about their difficult trek, Lewis' record from 19 September does give us a hint. He writes "set out this morning a little after sun rise and continued on our rout ... when the ridge terminated and we to our inexpressable joy discovered a large tract of Prairie country lying to the S. W." When their Indian guide told them the plain they could see bordered the

\footnotetext{
${ }^{6}$ Moulton. Journals. $5: 3$. ibid. 207.

${ }^{8}$ ibid. 9: 226. Whitehouse's entry for the same day says almost the same thing: see ibid., 11: 321. 
Columbia River, the news "greately revived the sperits of the party already reduced and much weakened for the want of food." The captains' journals do not give us many glimpses into what they were feeling during this arduous journey, but these comments by Lewis do provide a brief window - the fact that their "sperits" needed reviving is telling in this regard. The western environment had already had a powerful effect on the expedition, and would continue to do so.

After the party reached the plain they had seen from the Bitterroots, and the banks of the Clearwater River, they constructed dugout canoes and began descending the rivers. They soon encountered a different kind of difficulty-rapids. Lang writes that "the captains logged 29 troublesome rapids in 154 river miles on the Snake," and there were worse cataracts to come ${ }^{10}$ On 22 October the party reached Celilo Falls (called "the Great Falls" by the expedition) on the Columbia River, a short series of rapids where the river dropped nearly thirty-eight feet in about 1200 yards, according to Clark's calculations. The men portaged their supplies around these rapids on the north bank of the river, and then took the canoes to the south side where they carried them around the worst part of the falls and then lined the empty canoes down the remainder of the rapids with elkskin ropes. ${ }^{11}$

Immediately after Celilo Falls were the Short Narrows, a constricted portion of the Columbia where the entire river rushes through a channel about forty-five yards wide and a quarter of a mile long, according to Clark. The water here, he notes, "was

\footnotetext{
${ }^{9}$ ibid. $5: 215$.

"Lang. "Lewis and Clark." 142 . His information comes from the captains " Course and Distance" records. in Moulton. Journals. 5: 278-80.
} 
agitated in a most Shocking manner boils Swell \& whorl pools. . . ." Incredibly, after inspecting this rapid from the rocks above, the expedition ran it (Clark notes that it was a lot worse than he expected!). ${ }^{12}$ A few miles below the Short Narrows were the Long Narrows, a series of rapids Clark describes as being three miles long and 50 to 100 yards wide. ${ }^{13}$ Here the captains were more cautious, perhaps influenced by their experiences in the Short Narrows. They portaged their valuables around the rapids, and then ran the canoes through one at a time, placing men with ropes along the banks ready to rescue "any who Should unfortuanately meet with difficuelty," as Clark puts it, but they passed through without serious mishap. ${ }^{14}$ The final rapids they had to contend with were the Cascades, two wild cataracts separated by about seven miles of moderately rough water. After a difficult portage of canoes and equipment around the first rapid (Clark called it "the Great Shute"), the explorers decided to carry only their goods around the lower one, and run the canoes through it, which they did without any serious accidents

All of these rapids and portages must have taken their toll on party members. Remember, they had expected the Columbia River system to mirror the Missouri River, but they found the western river "quite unlike the upper stretches of the Missouri and its tributaries in Montana." 15 And there are hints during this period of struggle with the river that the explorers were beginning to react to this difficult and unexpected

\footnotetext{
"Moulton. Journals. 5: 322-324.

12 ibid. 328-33.

${ }^{13}$ See notations on Clark's maps in ibid. 330. 332. as well as courses and distances on 337. The Short Narrows and the Long Narrows together were known as "The Dalles" (ibid. 336n).

1.4 ibid. 338-39.
} 
environment. Lang notes a bizarre episode in mid-October when Clark entered an Indian lodge where the inhabitants were cowering, frightened, perhaps, by the sound of his gun. In his Field Notes Clark describes his attempts to calm the frightened people by passing out a few trinkets and smoking with them, and then he adds this disturbing sentence: "I am confident that I could have tomahawked every Indian here." Journal Entry, written later, Clark omits this shocking statement. ${ }^{17}$

Lang postulates that this incident "was an expression of Clark's frustration" with the Indians, but "it could also be that his frustration went deeper than that. . . The experience on the Columbia could well have begun to take its toll on him," and he "could have begun a process of losing control of the environment. The environmental conditions and his reactions to them," Lang continues, ". . . had become sufficiently disturbing that his confidence in the expedition's safety and ability to contend with the place had become shaken..." This lack of confidence, he believes, is one reason the expedition took such a chance in running the bad rapids at The Dalles: "to display their courage and to establish their own combativeness both with potential Indian foes and with the environment." environmental entities and conditions continued on the lower Columbia, as we will see.

\footnotetext{
${ }^{15}$ Lang. "Lewis and Clark." 142.

16 Moulton. Journals. 5: 303.

${ }^{1-}$ ibid. 305.

${ }^{18}$ Lang. "Lewis and Clark." $145-46$. The other reason for taking this chance. according to Lang. was to impress the watching Indians.
} 


\section{Fleas and Other Bothersome Creatures}

While the references to parts of the biological environment on the coast as they affected expedition members are not numerous in the journals, there are enough to show that the trend we saw concerning the environment on the upper Columbia continued, namely, frustrations and uncertainty on the part of the explorers, caused by not being able to control their surroundings. I will illustrate this pattern by examining accounts of an insect that irritated the two captains during their time on the coast more than any other non-human, living thing-fleas-and then discuss other creatures that party members complain about.

The first reference to these parasites after the party reached the lower Columbia is by Clark, on 6 November. He writes "the flees are verry troublesome which collects in our blankets, at every old village we encamp at."19 Fleas are again the subject of a negative comment by Clark on 8 November. The expedition stopped at "the remains of an old village" located in Grays Bay in modern Pacific and Wahkiakum counties, Washington. "Here," Clark records in his Journal Entry, "we found great numbers of flees which we treated with the greatest caution and distance."20

Clark's next reference to these bothersome insects is a month later. The party had arrived at the Fort Clatsop site on 7 December, and the next day Clark and five of the men "Set out to the Sea to find the nearest place \& make a way, to prevent our men getting lost and find a place to make Salt. ${ }^{, 21}$ After spending an uncomfortable night

\footnotetext{
${ }^{19}$ Moulton. Journals. 6: 26.

" ibid. 36

21 ibid. 116
} 
out in the open, the explorers met some Clatsop Indians who took them to their village which was located near the coast. The Indians were very hospitable, supplying the whites with food and lodging for the night-I will discuss this visit in detail in chapter 4. But even though the Clatsops supplied Clark with " 2 neet mats" to sleep on, he writes in his Field Notes "the flees were So troublesome that I Slept but little"; in his Journal Entry he records "I had not been long on my mats before I was attacked most violently by the flees and they kept up a close Siege dureing the night. ${ }^{, 22}$

The situation wasn't much better at the Fort Clatsop site. The party members, working diligently to complete the structure, were continually bothered by these parasites. On 12 December Clark writes 'the flees were So troublesom last night that I made but a broken nights rest, we find great difficuelty in getting those trouble insects out of our robes and blankets." ${ }^{23}$ And two weeks later there was still trouble with fleas. Clark writes "we dry our wet articles and have the blankets fleed, The flees are so troublesom that I have Slept but little for 2 nights past and we have regularly to kill them out of our blankets every day for Several past. ${ }^{.24}$

Only two days later Clark is again commenting on the fleas, but this time he discusses them in conjunction with the Chinook Indians. On 29 December he writes

The flees are So noumerous in this Countrey and difficult to get Clear of that the Indians have difft. Houses \& villages to which they remove frequently to get rid of them, and not withstanding all their precautions, they never Step into our hut without leaveing Sworms of those troublesom insects. Indeed I scercely get to Sleep half the night Clear of the torments of those flees, with the precaution of having my blankets

\footnotetext{
$2=$ ibid. 118-20.

23 ibid. 123.

$=4$ ibid. 138 .
} 
Serched and the flees killed every day - the $1 \mathrm{~s}$ of those insects we Saw on the Collumbia River was at the 1s Great Falls."25

Clark's Journal Entry says the same thing, though he uses different words.

When Lewis resumed writing on 1 January 1806, it didn't take him long to comment on the flea problem. On 2 January he writes "we are infested with swarms of flees already in our new habitations; the presumption is therefore strong that we shall not devest ourselves of this intolerably troublesome vermin during our residence here." Clark also continues to be irritated by them; he records "the flees are verry troublesome, our huts have alreadey Sworms of those disagreeable insect in them, and I fear we Shall not get rid of them dureing our delay at this place.,26 But, though the expedition remained at Fort Clatsop another two and one-half months, this is the last reference to fleas bothering the explorers at that site ${ }^{27}$

Complaints about fleas may seem a minor subject to discuss, but these descriptions are continuations of the frustration with the environment the captains exhibited on the upper Columbia. Just as they had felt helpless in the face of conditions on the Columbia Plateau, they felt powerless to escape the torments of the fleas. Lang notes that Lewis and Clark wrote their descriptions of parts of the environment "as if to bring the environment under some sort of logical management," but the flea trouble defied their every attempt to bring it under control. And Clark records a similar, isolated incident with another kind of creature on 5 November 1805 . He writes in his Journal

\footnotetext{
25 ibid. $1+2$.

${ }^{26}$ ibid. 161. Clark's independent entries continue for the first three days of January. as explained in the introduction.
} 
Entry "I [s]lept but verry little last night for the noise Kept dureing the whole of the night by the Swans, Geese, white \& Grey Brant Ducks \&c. on a Small Sand Island close under the Lard. Side; they were emensely noumerous, and their noise horrid."28 This entry again illustrates Clark's frustrations at his helplessness in the face of the environment, and the way various things on the lower Columbia are beginning to get under his skin. The day before he wrote this (November 4), Clark became particularly annoyed with the Indians living along the river because they pilfered his pipe tomahawk, as we shall see in chapter three. That night, he did not sleep well because the wildfowl were noisy. And, up to the first week of January, Clark continues to complain about various aspects of the environment, including the next subject I will discuss-the weather.

\section{The Overpowering Elements}

As the Lewis and Clark Expedition made its way down the Columbia River and passed through the Cascade Range, they "crossed one of the great climatological dividing lines on the globe," according to Lang, where "in just 25 miles, precipitation varies between 15 inches per year to more than $70 .{ }^{, 29}$ And it was not long before the explorers began to experience the effects of that change.

At first, Clark's entries are not particularly negative regarding the weather. For example, as the party traveled down the Columbia past Sauvie Island and to the vicinity

\footnotetext{
2- Clark does mention visiting an Indian lodge that was "full of flees" during a trip down the coast to see a beached whale (ibid.. 188. 191).

${ }^{28}$ Ibid. 23

${ }^{29}$ Lang. "Lewis and Clark." $1+2$.
} 
of modern-day Rainier, Oregon, he writes at the beginning of his Field Note entry for 5 November 1805 "a Cloudy morning Som rain the after part of last night \& this morning," merely describing the climatic conditions without critiquing them. Even when he writes "we are all wet, Cold and disagreeable, rain Continues \& encreases" near the end of that day's entry, he is commenting on, rather than condemning, the weather. ${ }^{30}$

He continues this practice for the next few days. As the party traveled through modern-day Grays Bay, Clark notes that it was "Cloudy and disagreeable all the Day," and says that "the Swells were So high and the Canoes roled in Such a manner as to cause Several to be verry Sick. ${ }^{311}$ But even though he obviously disliked the weather and conditions they were in, he does not seem very disturbed by their situation, as is evident from his 9 November entries, when in his Field Notes he writes "not withstanding the disagreeable time of the party for Several days past they are all Chearfull. ...,32

Clark's entries began to take on a more distressed tone over the next few days, as the expedition once again becomes helpless in the face of the environment. On 10 November the party cautiously made their way along the north shore of the Columbia and attempted to round Point Ellice, but were turned back by wind and high waves They were forced to make a camp on drift logs which, Clark notes, were "all on flote

\footnotetext{
${ }^{3(1)}$ Moulton. Journals. 6: 21

${ }^{31}$ ibid. 35 .

${ }^{32}$ ibid.. 38. The Journal Entry is almost the same.
} 
every high tide," 33 and they were trapped at this uncomfortable place until 12 November. Clark writes

a tremendious thunder Storm abt. 3 oClock this morning accompanied by wind from the S W. and Hail, this Storm of hard Clap's thunder Lighting and hail untill about 6 oClock at intervals it then became light for a short time when the heavens became darkined by a black Cloud from the S, W, \& a hard rain Suckceeded which lasted untill 12 oClock with a hard wind which raised the Seas tremendiously high braking with great force and fury against the rocks \& trees on which we lie, as our Situation became Seriously dangerous, we took advantage of a low tide \& moved our Camp around a point a Short distance to a Small wet bottom at the mouth of a Small Creek. . . ${ }^{34}$

Although Clark is still describing weather and not commenting on their situation, he is beginning to realize the coastal climate was something to be reckoned with.

By the $15^{\text {th }}$, Clark has had enough of the weather. The expedition had finally been able to make it around Point Ellice that afternoon, and were comfortably camped in huts they had constructed from boards they took from a "deserted" "I5 Indian village they found on the west side of that point. That night, Clark finally gave vent to his feelings, and his tone is almost incredulous when in his Field Notes he describes the expedition's experience during the last few days:

The rainey weather Continued without a longer intermition than 2 hours at a time from the $5^{\text {th }}$ in the morng. Untill the $16^{\text {th }}$ is eleven days rain, and the most disagreeable time I have experienced. Confined on a tempiest Coast wet, where I can neither get out to hunt, return to a better Situation, or proceed on: in this Situation have we been for Six days past. ${ }^{36}$

\footnotetext{
${ }^{33}$ ibid. 39

${ }^{34}$ ibid. +2

${ }^{35}$ The camp was probably vacant. but not permanently abandoned. I will examine this episode in chapter three. when 1 discuss exchange.

${ }^{36}$ Moulton. Journals. 6: 4 . Clark's emphasis. His feelings about their situation are also apparent in the names he gave Point Ellice: "Point Distress" ( ibid., 52), or the "Stormey point" (ibid., 53). 
Interestingly enough, Clark tones his description down in his Journal Entry, simply noting that when the wind calmed in the afternoon, the party was able to depart "this dismal nitich where we have been confined for 6 days passed, without the possibility of proceeding on, returning to a better Situation, or get out to hunt, Scerce of Provisions, and torents of rain poreing on us all the time. ${ }^{, 37}$ And in his Field Notes, there is relief in his tone as well, as if he feels that the worst of the weather must surely be behind them. But he would soon realize otherwise.

The party stayed in their comfortable camp on the west side of Point Ellice until 25 November, exploring the north side of the river's entrance and meeting and trading with the local Indians, and on the $21^{\text {st }}$ Clark again writes about the weather, noting in his Field Notes that the morning was "dark \& Disagreeable," and that the region had a "Supriseing Climent"; once again, he eliminates these comments from his Journal Entry. ${ }^{38}$ But on the $22^{\text {nd }}$, the conditions are bad enough that Clark describes them negatively in both entries. I will quote from his Journal Entry, and his words are again instructive enough to recite at length:

a moderate rain all the last night with wind, a little before Day light the wind which was from the S S. E. blew with Such violence that we were almost overwhelmned with water blown from the river, this Storm did not Sease at day but blew with nearly equal violence throughout the whole day accompaned with rain. $\mathrm{O}$ ! how horriable is the day waves brakeing with great violence against the Shore throwing the Water into our Camp \&c. all wet and Confind to our Shelters to day. ... ${ }^{39}$

\footnotetext{
ibid. 49

${ }^{38}$ ibid. 73

${ }^{30}$ ibid. 79
} 
Note the words he chooses to describe this storm: "violence" (three times in this short passage), "overwhelmed," and "horriable." Clark is no longer an impartial observer, recording what he is witnessing, but is railing against this facet of the environment that controls them. And when we recall that this passage is a Journal Entry, and therefore written months after the fact, we can comprehend just what kind of impression this storm had on him.

And his miserable experience with coastal weather continued after the party left their comfortable camp. Having decided to examine the south side of the river's mouth to see if it would provide a suitable place for a winter camp, the expedition left Point Ellice on 25 November. Because their canoes were not seaworthy enough to cross the Columbia near its wide and tempestuous mouth, they returned upriver several miles and crossed to the south side in the vicinity of today's Knappa, Oregon and wended their way down that bank of the river. They rounded Tongue Point (called "Point William" by the expedition) on 27 November, but then were once again trapped by the wind and waves, this time on the exposed west side of Tongue Point.

The next day, Clark describes yet another fierce storm. In his Field Notes he describes their predicament: "Several hunters attempted to penetrate the thick woods to the main South Side without Suckcess ... the wind to high to go either back or forward ... This is our present Situation,! Truly disagreeable." And if that were not enough, "about 12 oClock," he continues, "the wind Shifted about to the N. W and blew with great violence for the remainder of the day at maney times it blew for 15 
or 20 minits with Such violence that $I$ expected every moment to See trees taken up by the roots, Some were blown down." And the winds also brought something else: "Those Squals were Suckceeded by rain, !O how Tremedious is the day." 40

The weather finally abated enough to allow the party to continue down towards the river's mouth, and on 7 December they reached the site Lewis had selected for their winter quarters, a point on today's Lewis and Clark River, a tributary to Youngs Bay on the Columbia River near its mouth. But the change in setting did not bring any relief from the weather. On 15 December Clark and a party of sixteen men left the Fort Clatsop site to retrieve eighteen elk their hunters had killed on the $12^{\text {th }}$. These men stayed out all night, and on the $16^{\text {th }}$ Clark writes in his Field Notes "rained all the last night we Covered our Selves as well as we Could with Elk Skins, \& Set up the greater part of the night, all wet." And the weather didn't improve with daylight, as Clark's cryptic phrases indicate: "The winds violent. Trees falling in every derection, whorl winds, with gusts of rain Hail \& Thunder, this kind of weather lasted all day, Certainly one of the worst days that ever was!" Once again, Clark tones it down in his Journal Entries, simply writing "wind violent from the S E trees falling, rain and hail, we with Some risque proceeded on thro the high waves in the river, a tempestious disagreeable day., ${ }^{, 41}$

But this is the last description of the weather in such negative terms, though the party remained on the coast for another three months. There are other, more general, descriptions of weather conditions, of course, but neither Clark nor Lewis (when he

\footnotetext{
40id. 92 .
} 
resumes writing on 1 January) describe what they are experiencing in graphic terms like Clark uses above. The closest either of the captains comes to Clark's detailed depiction is in a weather observation remark on 1 January, where Lewis notes "the changes of the weather are exceedingly suddon," and then goes on to write about hail, rain, wind, thunder, and lightning in a descriptive, yet neutral, tone. ${ }^{42}$

So, just as we saw with complaints about the fleas, the negative comments on weather end soon after the new year. The captains still record atmospheric conditions for each day, but they are merely following their long-standing pattern in this, since they supply us with weather observations for virtually every day of the entire expedition. ${ }^{43}$ And a quick look at these tables for January, February, and March of 1806 proves that the conditions did not suddenly improve. So why did they (specifically Clark) stop complaining about the weather, and about the fleas?

There are several possible answers to that question. Perhaps they discovered some solution to the flea problem, although they surely would have mentioned this in their writings. Maybe after they moved into Fort Clatsop on Christmas Eve they were no longer so directly exposed to the winds and rains, and so were not so concerned by them. Or, possibly, they got used to the coastal weather and the annoying fleas so that neither bothered them anymore. And the fact that we do not have original entries from Clark after 3 January, since he was copying from Lewis, may have something to do

\footnotetext{
${ }^{41}$ ibid. 126-27.

12 ibid. 259. The captains kept brief tables describing the weather for each day. The same information appears in both Lewis and Clark's Journal Entries. so it is clear Clark is copying Lewis here. For other neutral descriptions of weather. see Moulton. Journals. 6: 140, 163. as well as the weather tables for February (ibid. 362-65) and March (ibid., 7: 42-46).
} 
with this; Lewis seems much more concerned with hiding his true feelings in the journals than does Clark. All of the above may have contributed to this sudden cessation in criticism of fleas and weather, but I feel there was something else going on that was also a reason-they were becoming acquainted with the Lower Chinookan Indians, and increasingly directed their negative comments, feelings, and actions toward them. The environmental elements were completely beyond their control, but they could do something about the Indians they considered light-fingered and greedy. In the following chapters I will examine expedition reactions to the human element of the coastal environment.

${ }^{43}$ See "Weather observations" in the index of each Moulton volume 
PART II

THE EXPLORERS AND THE INDIANS ON THE LOWER COLUMBIA 
As members of the Lewis and Clark Expedition made their way towards the mouth of the Columbia River in early November of 1805 , they encountered and endured unfamiliar environmental conditions, as described in the proceeding chapter. But they also encountered the Indians who lived in that environment--the various tribes of the Lower Chinook. And just as they found the weather conditions frustrating and unpredictable, so too these Indians seemed fickle and uncontrollable, as the following chapters will elucidate. But before beginning my examination of the relationships between the Lower Chinook and the white explorers, I need to supply some background material for chapters three, four, and five, which all discuss some aspect of exchange

\section{The Explorers, the Chinook, and Exchange}

Exchange processes among the Lower Chinook Indians are not easy for us to reconstruct. though we do have a basic understanding. Yvonne Hajda writes that they differed according to the "social situations in which they occur[ed] and the social relationships among the participants." She also states that "the distinctions among close kin, distant kin .... and strangers marked different exchanges in the Greater Lower Columbia." 1 For example, a transfer of goods or food between a guest and a host was not considered the same as one between two parties trading, nor was an exchange between related Indians the same as one between an Indian and a white. In addition, the

\footnotetext{
${ }^{1}$ Yronne P. Hajda. "Regional Social Organization in the Greater Lower Columbia.
} 
Chinook recognized "two spheres of exchange" that Lewis and Clark apparently were not even aware of: "food and a few locally specialized raw materials were exchanged for each other, as were valuables such as slaves, furs, and dentalia, but items of one group were not exchanged for items of the other.",

Hajda bases her description on the frameworks of exchange among indigenous peoples worked out by several anthropologists, but the works of only two are relevant here. The first is Marshall Sahlins, who defines exchange among such peoples as "reciprocity." This "is a whole class of exchanges, a continuum of forms. . . At one end of the spectrum stands the assistance freely given ... the pure gift. . . At the other pole. self-interested seizure, appropriation by chicanery or force... 'negative reciprocity.",3

He understands various exchanges as different forms of reciprocity, and these have a wide range. "Generalized reciprocity," or exchange between closely related people, is at one extreme in his scheme. In this context, goods are given to another with no expectation of return (although at some point there almost certainly is a reciprocal gift) In the center is what he calls "balanced reciprocity." Here, "the parties confront each other as distinct economic and social interests. The material side of the transaction is at least as critical as the social: there is more or less precise reckoning, as the things given must be covered within some short term." Such an exchange takes place between

1792-1830“" (Ph.D. Diss.. University of Washington. 1984), 205-06.

2 ibid.. 206.

${ }^{3}$ Marshall D. Sahlins. "On the Sociology of Primitive Exchange." in The Relevance of Models for Social Anthropologv. edited by Michael Banton. 139-236 (London: Tavistock Publications. 1965). 144 
people with more social distance than "generalized reciprocity." At the other pole from generalized reciprocity is "negative reciprocity." Sahlins describes this as "the attempt to get something for nothing with impunity." Methods used range from "haggling" to outright theft. ${ }^{4}$ These three categories are only guidelines, of course, and they shade into one another. ${ }^{5}$

The other relevant anthropological scheme is by Frederick Pryor. He recognizes two modes of distribution among primitive peoples: first, market exchange, which consists of a balanced flow of goods and services between persons and groups; and second, transfers, which do not involve a directly observable counterflow for the goods and services going from one person or group to another. ${ }^{6}$ Hajda prefers Pryor's scheme to that of Sahlins, in part because "markets are not ruled out," and "it eliminates judging motives (a problem arising particularly with Sahlins' 'negative reciprocity')."?

In chapters three and four of this section, I will follow a part of Sahlins' scheme for precisely this latter reason: while it is hard to discern motives from the sources, they are the driving force behind any transaction, and misunderstandings between the Chinook and the expedition came about largely because of their respective motives. For example, if Lewis and Clark approached an exchange motivated by a desire to get the most value for their goods, and the Chinook were looking for a balanced exchange,

\footnotetext{
4 ibid. 147-48.

${ }^{5}$ See figure one in Sahlins. "Primitive Exchange." 152.

${ }^{6}$ Frederic L. Pryor. The Origins of the Economy: A Comparative Study of Distribution in Primitive and Peasant Economies (San Francisco: Academic Press. 1977). 27.

Hajda. "Regional Social Organization." 28-29.
} 
there was bound to be resentment. Likewise, if the Chinook were motivated by the social distance between the two groups to drive a hard bargain, while Lewis and Clark simply wanted to get enough food to survive on, friction was the result. Therefore, chapter three will concentrate on negative reciprocity, while chapter four focuses on balanced reciprocity (the generalized reciprocity, or pure gift, of Sahlins' scheme is never realized during the Fort Clatsop winter) ${ }^{8}$

It is important to recall here that Sahlins stresses these categories are not exclusive and sharply defined. Rather, there is a considerable amount of gray area where one gradually shades into another. So, though I may assign a particular exchange between the expedition and the Chinook to one category, that exchange probably falls on the continuum somewhere between it and another, and so will have qualities that would allow it to be a part of the other category as well. In short, there will be some overlap Despite this, if we keep this limitation in mind, these categories can help us get a handle on the information from the journals

In chapter five, when I discuss the pure trade aspects of the expedition/Lower Chinook relationship, 1 will rely on the exchange part of Pryor's scheme because, as Hajda notes, he does allow for the market concepts of supply and demand. ${ }^{9}$ This is critical for understanding what was happening between the whites and the Chinooks when they attempted trade exchanges, since it is obvious both sides recognize supply and demand forces.

\footnotetext{
${ }^{8}$ Although there were gifts given by both expedition members and the Chinook. there was alwars some motive for these exchanges. and so they are not really "pure gifts."

"Pryor. Origins of the Economy, 31.
} 
At this point, I should also point out a slight difference in focus between what I will describe and what Hajda and the other anthropologists discuss. They are interested in what native exchange was like before any white contact, and I am concentrating on the Chinookan-white interchange. While their conclusions are important to me in establishing the cultural norms of Chinookan exchange, white contact had surely changed exchange practices of the Coastal Indians. Hajda even notes that "items of European origin, such as beads, were exchanged for both kinds of goods" (i.e., goods from both traditional spheres), indicating traditional exchange boundaries were somewhat blurred. ${ }^{10}$

It is also important to remember here that the expedition journal entries written late in (or after) the Fort Clatsop winter often indicate a striking difference in attitude when compared with those from early on in the winter, as discussed in the introduction. For example, Clark's Journal Entries, written after the expedition had already left Fort Clatsop, are frequently much more negative regarding the Chinook than his Field Notes. which were probably composed within a few days of the date under which they appear. This is important because it allows us to see how expedition members gradually grew more and more frustrated with the Coastal Indians, and because the pattern is the reverse of what we saw in the discussion on expedition reactions to the environment. While complaints about fleas and the weather died out as the winter went along, negative comments about the Lower Chinook increased, culminating in Clark's

\footnotetext{
${ }^{10}$ Hajda. "Regional Social Organization." 206. While the coming of the whites and their valuables certainly altered these traditional spheres, it had been less than thirteen years since Gray sailed his
} 
many disparaging remarks in his Journal Entries (written after the party left the lower Columbia) and in an almost shocking statement regarding Chinookan appearance by Lewis less than a week before the explorers left Fort Clatsop. But I am getting ahead of myself. Before discussing Lewis' passage, we need to consider the Chinookan exchange practices that so confused the captains.

ship into the Columbia. It is reasonable to conclude that some of the Chinook still held to the traditional trade practices. 


\section{CHAPTER 3}

\section{STEALING, OR NEGATIVE RECIPROCITY}

Members of the Lewis and Clark Expedition disliked several things about the Lower Chinook, but the perceived Indian propensity to pilfer troubled them the most. Ronda writes that the party considered the Chinookan people in general "incorrigible thieves,"1 and the evidence from the journals certainly shows that expedition members felt this way about the Coastal Indians. For example, in his Journal Entry on 4 November 1805, Clark notes that "they [the Chinook] are thievishly inclined as we have experienced,"2 and later in the winter, on 4 January 1806, Lewis agrees when he writes "these people the Chinooks and other residing in this neighbourhood . . appear to be mild inoffensive people but will pilfer if they have an opportuny to do so where they conceive themselves not liable to detection." But this was not always a simple matter of one group wanting and so stealing the belongings of another group, as it seems at first glance. In this section I will examine both the expedition and native viewpoints on this subject, showing how cultural misunderstandings led to much of the expedition resentment regarding Chinookan theft. We will see that the coastal Indians probably felt justified in what many of the expedition members considered outright

\footnotetext{
${ }^{1}$ Ronda. Lewis and Clark. 178.

'Moulton. Journals. 6: 19.
} 
theft, but since the explorers did not understand the native viewpoint, they branded them thieves, and their negative remarks become more pronounced as the winter goes along, as is evidenced by differences between Clark's Field Notes and Journal Entries.

\section{Stealing: Social Distance and Simple Greed}

For Lewis and Clark and the rest of the members of the expedition, the theft question was a clear-cut issue. In the ideal white world, one did not take things that obviously belonged to someone else, and that is what the Chinook were doing. But the world is not an ideal place, and just as there were (and are) whites who were ready to steal when the opportunity presented itself, there were probably Chinook Indians who would unscrupulously do the same. And we also need to consider the relative value of the goods members of the party were carrying, like guns, knives, and utensils. To the explorers they were fairly commonplace things that could be purchased at any store in the East. To them the major value of these goods came because they were thousands of miles from the nearest trading post that might have such items, and therefore they could not readily replace them.

On the other hand, to the Chinook these items were much more valuable. It is true that fur traders visited the Columbia River fairly regularly, but the expedition journals indicate that the Indians still greatly desired such simple items as beads and fishhooks, ${ }^{4}$ and though the natives did have a few guns, the superior weapons and the other iron implements carried by expedition members must have been very tempting items.

\footnotetext{
${ }^{3}$ ibid. 164
} 
Consider how the expedition members may have acted had they discovered the Chinook possessed large quantities of gold-the history of Spanish America gives us some hint of what the relationship may have been. To many natives, iron and goods of European or American manufacture were as valuable as gold was to the Conquistadors. ${ }^{5}$ So, simple greed played a part in the native theft. The Indians desired the American goods, and some were unscrupulous enough to simply steal them, especially when we consider their social distance from the whites. As Sahlins writes "the appropriation of another man's goods ... which is a sin . . in the bosom of one's community may be not merely condoned but positively rewarded with the admiration of one's fellows-if it is perpetrated on an outsider." This attitude can explain many of the thefts recorded in expedition journals.

This desire for weapons and goods of American manufacture, coupled with the social distance between the Chinook and the whites, was probably the motive for some incidents of theft on the $14^{\text {th }}$ and $15^{\text {th }}$ of November 1805 that Clark found especially troubling, perhaps because they involved expedition weapons. The expedition had been pinned in the small cove on the north side of the Columbia, just upriver from Point Ellice, since the evening of the $10^{\text {th }}$ by high waves and bad weather, and on the $13^{\text {th }}$ the captains sent three men-John Colter, George Shannon, and Alexander Willard—ahead to scout for a better campsite in a more seaworthy Indian canoe Lewis had purchased

\footnotetext{
${ }^{4}$ Blue beads were the native farorite; see Moulton. Journals. 6: 123. Also see "beads" in the index to rolume six. For fishhooks see ibid. 25-27: 30-31. as well as "fishhooks" in the index.

5 For a discussion of this among indigenous peoples in general. see T. A. Rickard. "Drift Iron A Fortuitous Factor In Primitive Culture." The Geographical Review' 24 (October 1934): 525-43.
} 
upriver. The next day Clark records that " 5 Indians Come up in a Canoe thro emence waves \& Swells, they landed and informed us they Saw the 3 men we Sent down yesterday, at Some distance below[.] Soon after those people Came," Clark continues, "Colter one of the three men returned and informed us that he had preceeded with his canoe as far as they Could. ..." He had seen "a good Canoe harber \& 2 Camps of Indians at no great distance below," and he also told the expedition that the Indians who were then visiting them "had taken his gig \& knife \&c. which he forcably took from them. ..."Clark concludes this story in his Field Notes by writing that the Indians "left us, after our treating them well."

One wonders what kind of force Colter used against the Indians that could be construed as "treating them well"; perhaps by writing this Clark was attempting to follow Jefferson's instructions to "treat [the various Indians they would encounter] in the most friendly \& conciliatory manner which their own conduct will admit." ${ }^{\prime 8}$ If that was the case, Clark was no longer worried about Jefferson's instructions when he wrote his Journal Entry of the experience some months later, for he records

5 Indians Came up in a Canoe... They made Signs to us that they Saw the 3 men we Sent down yesterday. only 3 of those Indians landed, the other 2 which was women played off in the waves, which induced me to Suspect that they had taken Something from our men below, at this time one of the men Colter returned by land and informed us that those Indians had taken his Gigg \& basket, I called to the Squars to land and give back the gigg, which they would not do untill a man run with a gun, as if he intended to Shute them when they landed, and Colter got

\footnotetext{
6' Sahlins. "Primitive Exchange." 153.

Moulton. Journals. 6: 46.

${ }^{8}$ Lar ender. IIestern Sea. 392.
} 
his gig \& basket I then ordered those fellows off, and they verry readily Cleared out they are of the War-ci-a-cum. ${ }^{9}$

Note the difference in the way Clark remembers treating the Indians: instead of "they left us, after our treating them well," he threatens to "shute" them and sends them packing, as if between the time this actually occurred and the time he wrote his Journal Entry he has decided "their own conduct will [not] admit" being treated in "the most friendly and conciliatory manner. ${ }^{\prime 10}$ It is also interesting to note how Clark takes pains to tell us what tribe these Indians are from, as though that explains the entire theft situation

The waves in the river were still too high for the party to act on Colter's information regarding the "good Canoe harber" he had seen below, so Lewis and three of the men "Set out down the shore" on foot, leaving Clark and the rest of the men to follow with the canoes when the weather permitted. At about three o'clock the next afternoon (the $15^{\text {th }}$ ) the wind abated enough to allow the party to paddle around "the blustering Point" that had impeded their progress "for Six days past."

Here they found the harbor Colter described and "a large village of 36 houses deserted by the Inds."-more about this later. Clark writes "Shannon \& 5 Indians met

\footnotetext{
${ }^{4}$ Moulton. Journals, 6: 47.

${ }^{16}$ The other differences between the two versions are also quite interesting: for instance, in the first. Colter tells Clark that the Indians had stolen his gig and knife from him, while in the second. Clark deduces the Indians have stolen something before Colter even appears. and then the Indians have stolen Colter's gig and a basket. There are a couple of possible reasons for these differences. First. perhaps Clark is telling the story more accurately when he is writing in leisure. instead of at a miserable camp on the shore of the Columbia. or second. maybe he is correcting misconceptions he had of the first encounter that further conversation with other party members cleared up.

"Moulton. Journals. 6: 48. They "blustering Point" is present-day Point Ellice in Washington state: Clark named it "Point Distress" on his map: see ibid. 1: map 82.
} 
me here, Shannon informed me he met Capt. Lewis Some distance below \& he took willard with him \& Sent him to meet me." But it was Shannon's final bit of news regarding Indian stealing that especially troubled Clark. He said the five Indians with him "wer rogues, they had the night before Stold both his and Willards guns from under their heads, Capt. Lewis \& party arrived at the Camp of those Indians at So Timely a period that the Inds. were allarmed \& delivered up the guns \&c." At this, Clark posted a sentinel over the expedition's baggage, and when four additional Indians came into their camp to trade, Clark writes "I informed those Indians all of which understood Some English that if they Stole our guns \&c the men would Certainly Shute them, I treated them with great distance, $\&$ the Sentinel which was over our Baggage allarmed them verry much ..." In Clark's Journal Entry for this day he writes that he told the five "Indians who accompanied Shannon that they Should not Come near us, and if any one of the nation Stold anything from us, I would have him Shot, which they understoot verry well"-he kicked them out of the expedition's camp, and also identifies them as "Chin nooks," or Chinook proper. ${ }^{12}$

His Journal Entry version of the arrival of the four additional Indians who came into their camp also identifies their tribe; they were "of the War-ki a cum nation," or Wahkiakum Indians. Clark writes that "I told those people [the Wahkiakum] that they [the Chinook] had attempted to Steal 2 guns \&c. that if any one of their nation stole

12 ibid. 6: 48-50: see also note 7 on page 51 . 
any thing that the Sentinl. Whome they Saw near our baggage with his gun would most certainly Shute them. . .,13

Clark continues his strict course over the next few days, as if he has finally decided the various Chinookan tribes are all thieves. For example, on 16 November, he mentions in his Field Notes that "The 5 Indian Theves left me." They had apparently been camped near, but not with, the expedition. Interestingly enough, in his Journal Entry Clark writes "The 5 (hin nooks left us"-by replacing "Indian Theves" with "Chin nooks" is he equating that tribe with thieves? ? ${ }^{15}$ Whatever his feelings about that particular tribe, his opinion of the Lower Chinook in general is clear, as is his notion on the correct way to stop the theft. On 22 November his Field Notes read "we find the Indians easy ruled and kept in order by a Stricter indifference towards them." ${ }^{" 16}$ His Journal Entry again explains this: "the threat which I made to the men of this nation whome I first Saw, and an indiffernce towards them, is: I am fully Convinced the Cause of their Conducting themselves with great propriety towards ourselves \& Party."17 For Clark, being strict and aloof are the keys to controlling the Indians, but this was hardly the best solution to a problem caused in part by the social distance between the two groups in the first place. Remember, one reason the Chinook were stealing from the expedition was that the party members were strangers, and Clark's actions certainly did not help the two groups become better acquainted.

\footnotetext{
13 ibid

${ }^{14}$ ibid. 51

15 ibid. 53: Clark's emphasis.

${ }^{16}$ ibid. 79
} 
Another incident of theft that demonstrates this social distance took place on 27 November 1805 . The captains had decided to winter on the south shore at the mouth of the Columbia River, but since their canoes were too unstable to attempt crossing the river near its mouth, the party traveled back upriver several miles before crossing to a place on the south shore near present-day Knappa, Oregon. The expedition stopped at a village of Cathlamet Indians and did some minor trading, and then continued down the river and camped. The next morning "at day light," Clark records, "3 Canoes and 11 men Came down" with food items for trade, but their prices were too high for the captains. Clark continues "as we were about Setting out, discovered that one of those Indians had Stole an ax, we Serched and found it under the roabe of one man whome we Shamed verry much."18 Once again, an Indian saw a chance to pilfer a valuable article from complete strangers, and took it.

And such petty thefts did not stop after the expedition arrived at the Fort Clatsop site. On 20 December 1805, Clark records a trading visit by three Indians. The next day, his Field Note entry tells us "the Indians were detected in Stealing a Spoon \& a bone, and left us. ..."In his Journal Entry, he identifies the object they attempted to pilfer as "a horn Spoon," and, and says that they were "turned from" the explorers' camp. ${ }^{19}$ Even after they had finished the fort and moved into it, Indians continued to try to steal from the expedition. On 18 February, both captains record a trading visit to Fort Clatsop by "eight Clasops and Chinnooks," who "remained untill late in the

\footnotetext{
15 ibid. 81

18 ibid. 90.
} 
evening and departed for their village. ${ }^{, 20}$ Lewis has nothing more to say about this visit, but Clark notes "Since their departure we have discovered that they have Stole an ax." No other expedition journal writer mentions this theft. ${ }^{21}$

This series of incidents, from the temporary theft of Colter's gig and knife to the ax pilfering, seems to be just a simple matter of the Indians wanting the belongings of these white strangers who were trespassing on their territory. In expedition eyes, this was proof that the Lower Chinook were habitual thieves, but in Chinook eyes it was perfectly natural to appropriate something you wanted from complete strangers. And something else needs to be considered here-the amount of contact these Chinook Indians had had with white traders, and how this contact shaped their attitudes toward whites in general

Lewis and Clark noted a difference between tribes who had been visited by traders, and those who had not. Clark told Biddle "Generally the Indians between the Rock Mountains \& the Falls - that is those who had had no intercourse with the whites were more ... hospitable than those below, i.e.: those who had known \& been corrupted by European connexion."22 At the mouth of the Columbia River, the Chinook proper on the north shore had had the most contact with traders visiting from the sea because that is where the river channel and best anchorages were. The Wahkiakum division of the Lower Chinook, who lived just upriver from the Chinook proper on the north shore,

\footnotetext{
${ }^{19}$ ibid. 134. Clark's emphasis

ibid. 325

$2 i$ ibid. 327.

: Jackson. Letters. 2: 543.
} 
had nearly as much contact with white men, but the Clatsops and the Cathlamets, living on the south shore at the mouth and further upriver respectively, had considerably less contact. The journals do not explicitly discuss how these varying degrees of contact had affected the different tribes of Lower Chinook, but they do imply some differences. For example, as noted above, on 16 November 1806 Clark writes "The 5 Indian Theves left me" in his Field Notes, while his Journal Entry reads "The 5 Chin nooks left us," seemingly equating the Chinooks with thieves. Also noted earlier is the Journal Entry on 14 November where Clark took pains to identify the Indians who had stolen Colter's knife and gig as Wahkiakum, as if this explained the entire situation. And when some Wahkiakum and "Skil-lute" Indians visited Fort Clatsop on the $30^{\text {th }}$ and $31^{\text {s }}$ of December 1805 , Clark writes that the latter, who were "from higher up the river" and presumably had less contact with whites, were "much better behaved than the II'ar ci a cum," who he describes as "very forward and disegreeable.",23

The question of why those Indians who had experienced contact with white traders would treat the explorers differently than those who had not is answered in the Lewis and Clark journals and in the narratives of several early Northwest Coast fur traders: early visitors to the Columbia River had often mistreated the Indians. For example, the Chinook told the captains about a trader identified as "Washilton," or "Fallawan," who visited the Columbia estuary and "fired on \& killed Several Indians. . .,24 Charles Bishop of the Ruby gives another example of such mistreatment, though his account

\footnotetext{
2.3 Moulton. Journals. 6: 145-47.

${ }^{24} \mathrm{ibid} .156$. The first name was crossed out by Clark in his entry.
} 
must be read critically since his journal clearly exhibits the prejudices toward Indians most whites of his era had ${ }^{25}$ He writes during his stay in the Columbia River that "the [Chinook] chiefs tell me three Masters of vessels that they are at war with, if ever they come here again. ..." The reason for this animosity was that these traders had "fire[d] on the Natives," and "several of the Chinnooks people were wounded," though none were killed. ${ }^{26}$ And Robert Gray, the American captain who first entered the river, resorted to violence against other Pacific Coast Indians several times. While he did not fight with the Lower Chinook at the Columbia River, he did kill several Indians at Grays Harbor only a few days before he discovered the Columbia. Boit writes that when they first entered the river the whites "observ'd some of the same people [they] had before seen at Gray's Harbour," and thought it might be a "branch of this same River. ${ }^{27}$ Finally, a Spanish exploring expedition that entered the Columbia in August of 1793 killed an undisclosed number of Lower Chinookans because the Indians thronged about their ship in their canoes and made threatening gestures. ${ }^{28}$ Basically, the white traders and explorers could be brutal and highhanded, and this certainly affected the way the Lower Chinook interacted with the whites in general, and Lewis and Clark in particular

\footnotetext{
25 "In short." writes Bishop. "you have to expect in these people all the Wiley guile ascribed to the Sarage race. as a stranger or an Enemy; and a Generous hospitality in their Friendship and confidance." See Elliott. "Journal." 268.

26 ibid.

$=$ Meany. "New Log." 27. 31-32. Boit also records cruelty by other traders on other parts of the coast. see 16-17.

${ }^{2 x}$ Wagner. "Last Spanish Exploration." 326-27.
} 
Lewis and Clark also resented theft among the Chinook because by the time they reached the Pacific Coast their trade goods were greatly depleted, and every loss was critical. The captains were worried about their lack of goods for the return trip, as is indicated in Clark's entry on 23 November 1805. Clark writes that the expedition was visited by "7 Indians of the Clatt Sopp nation," their first contact with the tribe they would winter among. These Indians brought two otter skins to trade, but they "asked Such high prices" the captains could not purchase them, Clark writes in his Field Notes, "with[out] reduceing our Small Stock of merchindize on which we have to depend in part for a Subsistance on our return home.,29

And there are other hints of this same concern. On 24 November, while discussing the expedition's decision to winter at the mouth of the Columbia River instead of returning upriver to build a fort, Clark lists as one of the reasons "a probibility of vessels Comeing into the mouth of Columbia ... from whome we might precure a fresh Supply of Indian trinkets to purchase provisions on our return home. . ."30 Lewis was also concerned about their dwindling supplies, as indicated in his 6 January 1806 entry. He remarks "our merchandize is reduced to a mear handfull, and our comfort during our return the next year much depends on it, it is therefore almost unnecessary to add that we much regret the reduced state of this fund." 1

\footnotetext{
${ }^{29}$ Moulton. Journals. 6: 81. In his Journal Entry for that day. Clark leaves out the "in part." implying their entire subsistence on the journey east relied on their trade goods.

3 ibid. 85 .

${ }^{3 !}$ ibid. 169
} 
Lewis' entry on 16 March 1806 indicates just how low their trade goods were, though we need to remember that this was only a week before the expedition left Fort Clatsop, so they had reduced their "fund" even more by trade with the Chinook during the winter. He writes

two handkercheifs would now contain all the small articles of merchandize which we possess; the ballance of the stock consists of 6 blue robes one scarlet do. one uniform artillerist's coat and hat, five robes made of our large flag, and a few old cloaths trimed with ribbon. on this stock we have wholy to depend for the purchase of horses and such portion of our subsistence from the Indians as it will be in our powers to obtain.

Clark's entry for that same day gives an even more dire report: he writes that a single handkerchief would contain all their goods. ${ }^{32}$ The captains had relied on such goods to purchase supplies they needed from various Indians they encountered during their journey west, and they would need to do so again during their return to the east. Since the expedition was very low on trade goods, Lewis and Clark feared that Chinookan theft would jeopardize the party on the way home by making it difficult to obtain needed supplies

\section{Stealing to Recoup Losses}

The Chinookan point of view on what the expedition considered outright theft may have been completely different. They may have considered what they took from the white explorers their just due as payment for use of their belongings or territory. Consider an episode that occurred soon after the expedition reached Lower Chinookan territory 
As noted in chapter two, as the expedition made its way down the Columbia River in early November of 1805 they encountered terrible weather and had a difficult time advancing through the wind and waves. From the $9^{\text {th }}$ to the $15^{\text {th }}$ of that month the party was pinned by high waves and strong wind just above Point Ellice. Their stay here was miserable and when the wind finally abated enough to allow the party to paddle around the point they found a "good Canoe harbor" houses deserted by the Inds.".34 The expedition soon found a use for this "deserted" village: near the end of his entry for the $15^{\text {th }}$ Clark writes "our men all Comfortable in their Camps which they have made of boards from the old Village above.,"35

The village may have been "deserted," but it was probably not permanently abandoned. According to Minor, "Occupation of the villages of the Chinook proper at the mouth of the Columbia River was of a seasonal nature, beginning in the late spring and continuing through the summer into early fall, during which time the major runs of Chinook salmon took place.",36 These Indians had other villages inland, on Willapa Bay, "generally considered winter villages. The occupation of these settlements began at the end of August. . .."37 So, the "old Village" the men robbed for boards was probably a summer encampment-Minor identifies three known sites in the area as "Summer Settlement[s]"38 - and since the expedition was there in November, the

\footnotetext{
32 Moulton. Journals. 6: 421-23.

3.3 ibid. 46

${ }^{3.4}$ ibid. 48

35 ibid. 50

${ }^{36}$ Minor. "Aboriginal Settlement." 52

$3^{-}$ibid. 56

${ }^{38}$ ibid. 55
} 
Indians had moved into their winter villages inland on Willapa Bay, protected from the kind of weather that kept the explorers uncomfortably pinned in the "dismal nitich"39 north of the "blustering Point" ${ }^{\text {"40 }}$ for so long.

One can only imagine what the Chinook thought as they watched a well-armed partly dismantle their summer houses. Perhaps they decided that if the white strangers would freely use the boards from their buildings, they were entitled to take whatever they could from the whites. And while Lewis and Clark probably did not realize that the Indians would want to return and live in this village the following summer, their ignorance would make no difference to the Indians who owned the houses. ${ }^{41}$

Perhaps a better example of the Lower Chinook "stealing" from the expedition to recoup losses of their own comes on 3 February 1806. According to Lewis, "Drewyer [George Drouillard, an expedition hunter] had killed seven Elk" near a Clatsop village, and the captain records "we are apprehensive that the Clatsops who know where the meat is will rob us of a part if not the whole of it." ${ }^{, 42}$ Their fears were well-founded, for when a group of men sent to get the meat returned to the fort on the $6^{\text {th }}$, Lewis writes that they only had "the flesh of about 2 Elk and 4 skins the Indians having purloined the ballance of seven Elk which Drewyer killed. ...43 From the expedition point of view, this was a clear-cut case of theft. One of their hunters-Drouillard-had killed (and presumably dressed) these elk, and when he went to get help to pack them out, the

\footnotetext{
${ }^{39}$ Moulton. Journals. 6: 49

40 ibid. 48.

4) The expedition also took boards from "an Indian house which is abandoned" to help in the construction of Fort Clatsop. See ibid.. 133.
} 
Indians took most of the meat and three of the hides. But from the Chinook viewpoint, the situation was not so simple. There is something else we need to consider here: who owned the elk roaming in the woods near Fort Clatsop? To the whites, they were simply wild game, free for taking. But among the Chinook, resource control was altogether different than what the American explorers were accustomed too.

While there is some question as to precisely how control of resources worked among the Lower Chinook, we do have some general models. For example, Allan Richardson believes that resources in a particular territory were controlled by villages in that region, and not individuals or families. Territorial borders were set by "River watersheds and adjacent saltwater areas," and such lands "were considered the shared territory of all communities resident within the catchment area, especially in reference to land mammals."4t On the other hand, Hajda questions Richardson's conclusions because "for the lower Columbia, data are largely lacking." She argues that his evidence is of a later date, and really only "pertains to the Salish area to the north." In her opinion, "It is quite likely that the village, household (= extended family), and perhaps individuals controlled different kinds of resources." Hajda maintains that it is "probable that villages did corporately own certain sites and resources....," but "individual or household control cannot be ruled out." 45

\footnotetext{
42 ibid. 275

${ }^{43}$ ibid. 281

${ }^{44}$ Allan Richardson. "The Control of Productive Resources on the Northwest Coast of North America." in Resource .Managers: North American and A ustralian Hunter-Gatherers. edited by Nancr M. Williams and Eugene S. Hunn (Boulder. Colorado: Westview Press. Inc.. 1982). 100. ${ }^{45}$ Hajda. "Regional Social Organization." 174-75.
} 
Whether resource control was at the individual, family, or village level does not really matter to us here. What is important is that the elk members of the Lewis and Clark Expedition were freely harvesting and eating belonged to someone else. As both Hajda and Richardson make very clear, the resources in the entire watershed area (Richardson specifically mentions "land mammals," and his source for this information was a Tillamook Indian, a tribe with close ties to the Lower Chinook) belonged either to the local Clatsop village(s), or families or individuals living there.

It is also important to understand that these elk were not merely a food source for the Lower Chinook, but were also a very valuable trade item. The Northwest Indians used elk hides as a kind of armor they called "clamons," and when the white traders came, they quickly learned how to profit from this item. There had long been a native trade in clamons between Indians living in the lower Columbia River region, where elk were plentiful, and tribes on Vancouver Island, where the armor was in great demand. When the white traders came, they became the middlemen, and using European goods would purchase clamons at the Columbia River and take them up the coast to Vancouver Island, where they traded them for what they really wanted--otter skins. ${ }^{46}$ Lewis and Clark were aware of this trade in clamons, according to the Nicolas Biddle notes. Clark told him that the New England traders who visited the Columbia River "carry from the U.S. trinkets old arms \&c. with which they trade for what they can get

\footnotetext{
${ }^{46}$ Howay. L'olages of the Columbia. 32 and note: 260 note: Robert H. Ruby and John A. Brown. The Chinook Indians: Traders of the Lower Columbia River (Norman. Oklahoma: University of Oklahoma Press. 1976). 61-62.
} 
of sea otter \& elk skins particularly - these they take (the elk Skin) further north \& exchange for Sea Otter which they take to the East Indies." ${ }^{, 47}$

So, elk skins were used by the Lower Chinook to obtain the European goods they wanted, and in their eyes Lewis and Clark were not merely stealing a part of their food supply, but were also appropriating a potential source of income. And the explorers were killing considerable numbers of elk. Just before the party left Fort Clatsop, Whitehouse wrote "the party has killed 155 Elk \& 20 Deer since we came to this place. ${ }^{\$ 8}$ Gass counts 131 elk and twenty deer, ${ }^{49}$ and Ordway puts the total at "150 odd Elk" and twenty deer. ${ }^{50}$ Whether the number is the highest or the lowest, that is a lot of elk

When we understand Lower Chinookan resource control and the value elk held to these Indians, it is obvious that the Clatsops must have considered it particularly insulting when Lewis and Clark demanded compensation from them for the "pilfered" elk. Neither of the captains record how they went about settling the matter, but we do know some general agreement was reached because on 12 February 1806 Lewis records "this morning we were visited by a Clatsop man who brought with him three dogs as a remuneration for the Elk which him self and nation had stolen from us some little time since. ..." These "dogs took the alarm and ran off,"s1 but ten days later Lewis records that Drouillard went to the Clatsop village "to get the dogs which the

\footnotetext{
$4^{-}$Jackson. Letters, 2: 541.

${ }^{48}$ Moulton. Journals. 11:430

${ }^{49}$ ibid. 10:199

"ibid. 9: 278
} 
Clatsops have agreed to give us in payment for the Elk they stole from us some weeks since," and on the $24^{\text {th }}$ of February, he returned to Fort Clatsop with two dogs. ${ }^{52}$

It is noteworthy that the Clatsops did not give the expedition very much compensation for the elk. Three dogs certainly do not add up to the meat of five elk and the hides of three, which is what the Indians got out of this agreement. I am sure the Clatsops considered it a particularly brazen effrontery to ask anything for what they considered their elk, but felt three dogs a small price to pay to keep peace with their new neighbors, especially since the Chinook apparently did not value dogs very highly (the captains note that "the natives do not eat them nor appear to make any other use of them but in hunting the Elk. ..."53). Expedition members obviously felt they were getting shortchanged in this exchange, because they used this episode to justify an action that Ronda calls "at worst criminal and at best a terrible lapse of judgment" and "a particularly sordid tale of deception and friendship betrayed"- the notorious theft of a Clatsop canoe by expedition members ${ }^{54}$ an incident that I will examine in chapter five

It is obvious that many of the episodes Lewis and Clark considered outright theft were seen differently by the Lower Chinook. While some of the pilfering probably stemmed from a simple native desire for expedition goods, and the fact that the Indians and the whites were strangers, the explanation of other incidents is not so clear-cut.

\footnotetext{
51 ibid. 6: 299

52 ibid. 342 . There is no comment on why Drouillard returned with two dogs instead of the original three

${ }^{53}$ ibid. 318; also see 319.275.
} 
For example, the Lower Chinook probably stole to recoup losses for the boards the expedition helped themselves to, and for the many elk killed in the Clatsop territory, both of which belonged to Chinookan villages, families, and/or individuals, something that Lewis and Clark obviously did not realize. In their view, the village was uninhabited, so the materials were theirs to take. Likewise, the elk were roaming wild in the woods, and so were fair game. But to the Chinook Indians, these were valuable resources, and when the whites used them at will it must have caused resentment, and it is probable this resentment spilled over into incidents of theft when the opportunity presented itself. But since the explorers did not consider the Chinookan point of view, they became more and more frustrated with them as the winter moved along, as Clark's more negative Journal Entries indicate. When he copied Lewis' account of the Indians taking some of the elk Drouillard had killed on this occasion, he added a comment of his own that is telling in this regard: "I find that those people will all Steal." 55 And there are other incidents of what the captains considered stealing which need to be considered from the Indian perspective, and this brings us to gifts among the Indians.

\section{Stealing and Harassment in Lieu of Gifts}

Another area where there was considerable cultural misunderstanding between members of the Lewis and Clark Expedition and the Lower Chinook was in gift giving. Lewis and Clark obviously realized the importance of gifts to Indians in general, because much of what they brought was for that purpose and they handed out many

\footnotetext{
${ }^{5}$ Ronda. Lewis and Clark. 210-11

ss Moulton. Journals. 6: 282.
} 
gifts on their journey across the continent. But when they finally reached the Pacific, things were different. As Ronda notes, "once lavish with their gifts to the Indians along the Missouri, the explorers were reduced to a very short supply of trade goods," ${ }^{, 56}$ and as a result they did not give many gifts to the Lower Chinook. The few they did pass out were not very impressive to Indians with such long-standing contact with white traders. But gifts were very important in Lower Chinookan culture for establishing and maintaining relationships between groups and individuals

That the coastal Indians were used to receiving gifts from whites is recorded by Clark. In "A List of the names of Sundery persons, who visit this part of the Coast for the purpose of trade \&c. \&c. in large Vestles" he describes a "Mr. Haley" who "is the favourite of the Indians (from the number of presents he givs)," indicating that giftgiving by the whites was common. ${ }^{57}$ As a result, the expedition stinginess in passing out gifts was not something the Lower Chinook easily understood. Most of the white men they saw were traders, who realized the importance of gifts and came adequately supplied with a variety of presents for potential customers.

Lewis and Clark gave out few enough non-food gifts among the Lower Chinook to list in full, and when we compare the following list to the bundles of goods prepared for the Missouri Indians, one reason those Indians were often more hospitable to the white explorers than the Lower Chinook is obvious: the expedition was more hospitable to

\footnotetext{
Ronda. Lewis and Clark. 190-91.

5oulton. Journals. 6: 155
} 
them. The following is a complete list of expedition gifts given to Indians while on the Lower Columbia River when no gift was received in return.

Clark records on 20 November 1805 the captains gave medals to the Chinookan chiefs Comcomly and Shelathwell, and a flag to one of them, though he doesn't tell us which. The next day Clark records that he "made a chief \& gave a medel" to an Indian named "Tow'wâll" who appeared "to have some influence with the nation [the Chinook?]" (this man lived "at the great Shute," or Cascades, up the Columbia, and so was probably not even a Lower Chinookan Indian) ${ }^{58}$ That same day Clark writes that the captains "divided Some ribin between the men of our party to bestow on their favourite Lasses, this plan to Save the knives \& more valueabel articles, ${ }^{, 59}$ though the expedition members probably used this ribbon to purchase sexual services and not as gifts to establish cordial relations. On 12 December, while the expedition was building Fort Clatsop, two canoe loads of Clatsop Indians visited the whites. In his Field Notes Clark writes "I made a chief of one \& gave him a Small medel. . ." El Eleven days later Clark records a visit to the fort by another two canoes of Clatsops, and says in his Field Notes he "gave a string of wompom to a Chief, and Sent a Small pice of Simimon to a Sick Indian in the Town who had attached himself to me. ${ }^{, 61}$ This last Indian he identifies as "Cus-ka-lah" in his Journal Entry, a man Clark had met on a visit to his village 1 will discuss in the next chapter. On 29 December 1805 Clark describes a visit

\footnotetext{
is ibid. 72-73.

${ }^{59}$ ibid. 74

5i ibid. 123. This Indian was a Clatsop leader named Coboway: see note 3 on page 123

6) ibid. 135
} 
from Coboway, the chief of a nearby Clatsop village, and says "I gave the Cheif a razor. ${ }^{62}$ On 3 January 1806, Coboway visited the fort again, and Lewis gave him "a pare of sattin breechies. ..,63 On 10 January Lewis records a visit by the chief of the Cathlamet Indians, and writes "I gave him a medal of the smallest size." February 1806 Lewis mentions a visit by "Tâh-cum a principal Chief of the Chinnooks and 25 men of his nation. We had never seen this chief before," Lewis continues, so "we gave this chief a small medal with which he seemed much gratifyed."65 The next day Lewis writes of a visit by "3 Clatsop," and since "they are great begers," he "gave one of them a few nedles with which he appeared much gratifyed." March 1806 (the day the expedition left Fort Clatsop to begin their return journey), Coboway again visited the whites, and Lewis writes "to this Cheif we left our houses and furniture"-not really the generous gift it seems, since the Fort was built in Clatsop territory, and the expedition certainly couldn't take it east with them. ${ }^{67}$

This is not an impressive total, especially when compared with a list of gifts intended for the " 1 st Chief" of some nation "beyond the mandanes" (on the upper Missouri, in present-day North Dakota or Montana): "1 Chief's Coat, 1 Medal 2d sise, 1 pr Leggins, 1 Britch Clout, 1 White Shirt, 1 Small Bundle Gartg., 1 lookg. Glass, and 1 Burning Glass." The gifts set aside for the second and third chiefs were nearly as impressive, and there is even a long list of goods ranging from "Ear Wire" to

\footnotetext{
52 Moulton. Journals. 6: 142

${ }^{63}$ ibid. 163

iti ibid. 192

65 ibid. 330 .
} 
"Wampum Shells" that were intended for such various secondary notables as "women of consideration" and "Chiefs Sons." better relations with tribes before they reached the Pacific Coast was that they gave them more presents. The total list of presents given to all important Indians during the winter among the Lower Chinook is not as impressive as the catalogue of goods intended for one chief on the Upper Missouri.

But since gift giving was very important among the Chinook, this was a significant deficiency on the part of the whites. According to Hajda, "The presents accompanying trade between whites and Indians seem to represent an aboriginal pattern, though no such exchange between Indians is documented." Hajda continues "such presents evidently signaled intent to trade peacefully and regard the respective rights of the parties involved." She also notes that though the whites had a hard time grasping this purpose of gifts, their own accounts supply evidence that the Chinook Indians were giving them gifts to establish or maintain relations. For example, Bishop of the Ruby describes his success in trading for furs among the Lower Chinook in May and June of 1795 , and notes that on 4 June "the natives very frankly told us they had no more." The day after this he records "the Natives brought us a large moose dear and 3 fallow dears . . ., ${ }^{69}$ While he probably did not realize it, this gift served a distinct purpose for the Chinook, as Hajda notes-it promoted peaceable trade. But "such present-giving

\footnotetext{
65. ibid. 333.

$6^{-}$ibid. $4+4$.

68 ibid. 3 : 496-97
} 
is not always easy to separate from the trade itself," and this lack of understanding could lead to problems. "Whites," she continues, "later got into considerable trouble, especially at the Cascades, apparently for not following this custom."

An example of such "trouble" is the several conflicts between the Upper Chinook and the fur trading Astorians at the Cascades in 1811 and 1812. Various journal writers among these traders record that as they made their portage around the rapids, the Indians often carried off entire bales of goods, threw large rocks at both the traders and their goods, demanded that they (the Indians) be hired to portage the trade goods around the rapids and then pilfered what they could during the passage, crowded around the whites to obstruct their passage, and even resorted to violence to impede the progress of the fur traders. ${ }^{71}$ These traders, like Lewis and Clark before them, considered the Chinook Indians thieves, "Villains," and "thorough-bred hypocrites and liars. ${ }^{, 73}$ but such pejorative descriptions do not really explain what is happening here.

\footnotetext{
${ }^{69}$ Hajda. "Regional Social Organization." 230: T. C. Elliott. "Journal." 263. There were no moose on the lower Columbia. but an abundance of elk. and this is probably what the Chinook gave Bishop.

"Hajda. "Regional Social Organization," 230.

${ }^{-1}$ See Robert Stuart. The Discovery of the Oregon Trail: Robert Stuart's Narratives of His Overland Trip Eastward From Astoria in 1812-13, Philip Ashton Rollins, editor (Lincoln: University of Nebraska Press. 1995). 55-59; Alexander Ross, Adventures of the First Settlers on the Oregon or Columbia River (New York: The Citadel Press, 1969), 118-22; Gabriel Franchère, Adventure at Astoria. 1810-1814. translated by Hoyt C. Franchère (Norman, Oklahoma: University of Oklahoma Press. 1967), 92-99. For later troubles, see Ross Cox, The Columbia River: Or Scenes and Adventures During a Residence of Six Years on the Western Side of the Rocky Mountains Among larious Tribes of Indians Hitherto Unknown; Together With "A Journey Across the American Continent, " edited by Edgar I. Stewart and Jane R. Stewart (Norman. Oklahoma: University of Oklahoma Press. 1957). 80-81.

$\because$ Stuart. Discovery of the Oregon Trail, 59.

${ }^{-3}$ Cox. Columbia River. 80.
} 
This "trouble" between the Upper Chinook and whites at the Cascades is commented on by David French. He writes 'the harassing behavior of the Indians can be interpreted ... as attempts to maintain or re-establish their position of importance." He continues "the thefts from the Whites would arise, then, not from a fundamental lawlessness . . but rather from a temporary dislocation of relation which might be remedied if pressure were applied . . through thefts or 'incidents.' These would serve to re-establish, not to break, relationships." What the white visitors in Chinookan territory often considered stealing by the Indians was in fact an attempt to force the whites to play by their rules. The Indians wanted the whites to give them gifts that would establish a relationship, and that they felt they were entitled to in return for passage through their territory.

When Lewis and Clark passed through the Cascades, they experienced exactly what French describes. On 22 October 1805, the expedition faced a difficult portage at Celilo Falls in the Columbia River Gorge, and Clark writes in his Field Notes that they "hire[d] Indians to take our heavy articles across the portage."75 But when he later expanded this into his Journal Entry, he described the Indians much more negatively. He writes that the party "took every article except the Canoes across the portag where I had formed a camp on ellegable Situation for the protection of our Stores from thieft, which we were more fearfull of, than their arrows ... Indians assisted us over the

\footnotetext{
"French. "Wasco-Wishram." 353.

"s Moulton. Journals, 5: 320 .
} 
portage with our heavy articles on their horses. ..."76 And when Clark discussed this encounter with Nicholas Biddle some four and one-half years later, he added yet another negative comment to this last sentence: "But for this service they repaid themselves so adroitly"-a clear case of theft, in his eyes. ${ }^{77}$ The explorers also had similar difficulties with Indians on their return back up the Columbia River at the Cascades, The Dalles, and Celilo Falls. ${ }^{78}$ But the Chinook were not the incorrigible thieves expedition members and later white traders believed them to be. By pilfering small items, they were "remind[ing] the white men of the need to offer respect and attention to the trading lords of the Columbia," but "theft as a means of creating mutually rewarding reciprocal relations was a notion utterly foreign to the explorers. It made far more sense in their world to see river people as . . cunning thieves." ${ }^{, 79}$

This type of Indian "theft," or harassment, followed the expedition down the river On 4 November 1805, as they approached the area of present-day Portland, the expedition stopped at a village with "25 Houses." "This village," Clark continues in his Journal Entry, "contains about 200 men of the Skil-loot nation I counted 52 canoes on the bank in front of this village...."80 In his Field Notes Clark says "we were treated verry kindly by them, they gave us round root near the Size of a hens egg

\footnotetext{
${ }^{-6}$ ibid.. 323.

Rueben Gold Thwaites. editor. Original Journal of the Lewis and Clark Expedition 1804-1806.

Volume 3 (New York: Arno Press. 1969), 148 note 2.

${ }^{-8}$ Moulton. Journals. 7: 96-155

${ }^{-9}$ Ronda. Lewis and Clark. 172.

${ }^{81}$ Moulton. Journals. 6:17.
} 
roasted which they call Wap-to to eate." about 4 bushels of this root," and continued on down the river.

When they stopped to eat dinner on an island about seven miles below the village, something interesting happened, and though the Indians involved were not Lower Chinookans, the incident is worth discussing for two reasons. First, it illustrates very well how the expedition completely misinterpreted a situation involving Indians. Second, Clark's accounts of this event indicate very well how his attitude had changed by the time he wrote his Journal Entry. In his Field Note entry for that day he simply writes "Indians continue to be with us. .. dureing the time I was at Dinner the Indians Stold my tomahawk which 1 made use of to Smoke I Serched but Could not find it ...".82

Clark greatly expands upon this event in his Journal Entry. He writes

Soon after [they stopped to eat] Several Canoes of Indians from the village above came down dressed for the purpose as I Supposed of Paying us a friendly visit, they had Scarlet \& blue blankets Salors jackets, overalls, Shirts and Hats independent of their Usial dress; the most part of them had either war axes Spears or Bows Sprung with quivers of arrows; Those fellows we found assumeing and disagreeable dureing the time we were at dinner those fellows Stold my pipe Tomahawk which They were Smoking with, I imediately Serched every man and the canoes, but Could find nothing of my Tomahawk, while Serching for the Tomahawk one of those Scoundals Stole a Cappoe of one of our interpreters, which was found Stufed under the root of a treer. ... we became much displeased with those fellows. . . ${ }^{83}$

\footnotetext{
${ }^{81}$ ibid. 15

82 ibid. 15-16.

${ }^{83}$ ibid. 17-18. A "Cappoe" is a "capote. or blanket coat"-see note 19 on page 20.
} 
When Clark and the other party members saw the Indians coming dressed in their finery, he was expecting a pleasant social visit, but the expedition got more than they bargained for. But this is not just a simple case of theft; something else is going on here

It seems strange that Indians from a village that had treated the whites so well only hours before would suddenly become "assumeing and disagreeable" and steal things from the party for no reason. But in the minds of expedition members, this is precisely what happened, and this reinforced their beliefs regarding the unpredictability of these river Indians. But once again, this seems to be a classic case of the "harassing behavior" described by virtually all of the early river explorers and traders, and explained by French. According to him, these Indians were not hardened criminals, as Clark (and the Astorians) described them. Rather, the expedition was not playing by the rules, and the Indians were confused and attempting to force the whites to recognize them as people to be reckoned with.

I need to make it clear here that $\mathrm{I}$ do not think Clark is embellishing his earlier account, but is probably describing events that really happened. What interests me is that he did not bother to record some occurrences in the first place (like the theft of the "Cappoe"), and he later added such value judgments to his description of the Indians as "assumeing and disagreeable" and "Scoundals." These additions to his original account indicate that he was more concerned with this incident after spending an entire winter among such Indians than he was when it occurred. The last sentence in his Journal 
Entry under that date is especially telling in this regard: "they [the Indians] are thievishly inclined as we have experienced. ${ }^{, 84}$ There is no corresponding statement in his Field Notes.

This entire episode is reminiscent of something that happened to the British sailors under Lieutenant Broughton when they explored the river in October of 1792. On the $28^{\text {th }}$ of that month, according to an account written by Edward Bell (Broughton's clerk on the (hatham), the exploring party "pass'd a very large Village, from whence a considerable number of Canoes came off, many of which carried $10 \& 12$ men, the greater part of whom were dressed in their War Garments, and arm'd with Bows \& Arrows, we computed that there were near two hundred Indians about us. ..." Despite their appearance, these Indians were "friendly \& peaceable," and the two groups engaged in a considerable trade. Bell writes "every man seem'd eager to dispose of his Bows and Arrows for old Buttons, Beads, \&c. . .".85

Vancouver's summary of Broughton's report to him also describes this incident, and he mentions a similar meeting between whites and Indians the next day. His account of this other meeting describes what was probably the reason relations between the two groups were so cordial: "On some trivial presents being made, a trade immediately commenced, in which the Indians conducted themselves with the utmost decorum." Broughton's party probably did not suffer the kind of harassment the Lewis and Clark

\footnotetext{
${ }^{84}$ ibid. 19.

${ }^{85}$ J. Neilson Barn. "Columbia River Exploration. 1792." Oregon Historical Quarterly 33 (March 1932): $143-44$

${ }^{86}$ Vancouver. lovage of Discovery. 757.
} 
Expedition did for two reasons: one, they were probably the first white men most of the Indians had ever seen, and their European goods appealed to the Indians (Vancouver reports that the Indians "would neither part with their copper swords, nor a kind of battle-axe made of iron," an indication of how they valued items of European manufacture) ${ }^{87}$ Two, and most important, they played by the rules. When the groups first met. the whites presented gifts, and this established their peaceful intentions. It is notable that no expedition journal mentions giving the Indians who stole Clark's pipe tomahawk, and who Clark found "assumeing and disagreeable," any kind of gift, even though all record receiving roots to eat from the Indians. ${ }^{88}$ Remember, according to Hajda, among the Chinook presents were exchanged as evidence of "intent to trade peacefully and regard for the respective rights of the parties involved." ${ }^{\prime 99}$ When Lewis and Clark did not reciprocate the gift, the Chinook felt a need to establish the relationship in another way, and so they visited the expedition camp and harassed the Americans. Something Hajda wrote regarding the Astorians is applicable here: "it was the whites' failure to act according to local ideas of propriety in such situations that led to such behavior." 90

While these events refer to various groups of Indians living upriver from the Lower Chinook, there is also evidence that the Coastal tribes acted in similar ways. The

\footnotetext{
$8^{-}$ibid.

${ }^{88}$ Clark clearly states in his Field Notes and Journal Entry that the Indians gave the expedition Wapato roots to eat. and then the whites purchased more of them. Ordway (Moulton, Journals. 9: 249). Gass (ibid. 10:166) and Whitehouse (ibid., 11:385) merely recount purchasing some of the roots.

${ }^{84}$ Hajda. "Regional Social Organization." 230.

ibid. 243.
} 
Lower Chinook gave the Spanish exploring expedition that entered the Columbia River in 1793 a comparable reception. Zayas, the second pilot of the ship Mexicana, writes that the ship entered the river 10 August 1793 and anchored in Baker Bay. The next morning, "the natives came out with a great array of bows and arrows. . ." The Spaniards decided to "continue up the Columbia River to seek its source," and did so, "being followed by innumerable war canoes, manned by corpulent, strong people of good appearance." But after going about fourteen miles, they ran aground, much to the delight of the Indians who were still following them. Zayas writes "the Indians rejoiced at our misfortune and were so insolent that the more we asked them to go away so we could extract ourselves from this dangerous situation the closer they came, bending their bows and wetting the feathers on their arrows. ${ }^{91}$

To this point, this is the same crowding and harassment Lewis and Clark experienced further up the river, albeit somewhat more threatening. But unfortunately, Zayas' account takes a tragic turn here. He continues "it was therefore necessary to take our arms in hand. These they did not think would do anything more than make noise until they saw the ravages made in one of their canoes." This apparently drove the Indians away, because the sailors were able to extricate the Mexicana from the sandbar, turn around, and sail back down the river; they abandoned their intentions of exploring the river because they would have had to do so in a launch, dividing their forces. ${ }^{92}$

\footnotetext{
41 Wagner. "Last Spanish Exploration," 326-27.

ibid. 327.
} 
This was such a radically different reception than the Lower Chinook gave Gray and Broughton a year earlier that we have to wonder why. Unfortunately, Zayas does not supply us with enough information to understand what happened. He does state that the Indians at the mouth of the river "would not permit [the Spanish] to hold any intercourse with them in spite of the fact that [they] had made them some presents," but this comment comes at the end of his Columbia River account, leaving one to wonder whether the gifts were offered before or after the Spanish fired upon the natives. And the reception these Spanish explorers received by the Lower Chinook is even more puzzling when we realize the schooner Resolution traded successfully with these very Indians sometime during August 1793, about the same time the Mexicana visited the Columbia River ${ }^{93}$ Whatever the motives behind the actions of either group, this account illustrates Lower Chinookan willingness to use harassing or threatening behavior to get what they wanted.

There is also other evidence the Lower Chinook were very jealous of their position as middlemen between the white traders and the various Indians living up the Columbia, and so would attempt to force whites to acknowledge them as "trading lords of the [lower] Columbia." In 1809 three fur-trading brothers from Boston-Abiel, Jonathan, and Nathan Winship-decided to establish a trading post on the Columbia River. They outfitted one of their ships, the Albatross, and, with Nathan Winship in command, sent it to the Pacific Coast; it entered the Columbia on 26 May 1810. They went upriver about forty miles and began building a fort, "But unfortunately the spot

${ }^{93}$ Howay, "The Resolution," 208-209. 
chosen lay so low that the summer freshets covered it with water to the depth of one or two feet before the building was completed." They chose a higher spot just down river and began floating their logs to it, "but in the meantime the natives became so troublesome that Captain Winship determined for the present to withdraw." ${ }^{94}$

William Gale, the journal keeper, describes what the Indians did that was so "troublesome." On 10 June he writes "this afternoon several canoes arrived from Chinook and Cheheelees, ${ }^{95}$ containing many natives, all armed with bows and arrows, or muskets... At 4 o'clock the next morning," he continues, "the shore gang was sent on shore to work as usual, which they continued until $11 \mathrm{~A} . \mathrm{M}$,, when [the whites] observ[ed] that the Indians, with their arms, began to gather where the people were at work..."The traders were alarmed by this, and called the men to the ship. Later that day "again the men were sent on shore to resume their work ... when the Indians gathering around them in considerable numbers ... the hands declared they did not feel safe to be on shore without arms," so they were called back to the ship. The Indians continued their harassment, "firing their muskets and shouting. One of the savages pointed a musket at Captain Winship . . but did not fire. ${ }^{" 96}$

Along with his description of the harassment, Gale also supplies the reason for it: "One thing is certain, the Chinooks are strongly set against our coming up the river, wishing, as they say, the house should be built among themselves and the lower tribes

\footnotetext{
${ }^{94}$ Bancroft. Korthwest Coast, 1800-1846. 133.

95 Probably Chehalis Indians. "a Salish-speaking people living in Gray Harbor and Pacific counties on the southern Washington coast." Their territory "extended southward to Willapa Bay, where the north
} 
[because] the settlement being established so far up will tend to injure their own trade ..." "97 The Chinook "troubled" the Winships because they were jealous of their position as middlemen in the Columbia trade. When Lewis and Clark had come down the river five years earlier, the Indians they met may have had different concerns, but they used the same methods to gain control of the situation: veiled threats and harassment. If the whites had given gifts to the local Indians like Broughton did, this would have gone far in establishing the relationship the Indians sought

Something Verne Ray noted concerning the Lower Chinook and warfare can also help us understand what is going on here with Broughton, the Spanish explorers, Lewis and Clark, and the Winships. "Warfare among the Lower Chinook," he writes, "was relatively infrequent and quite bloodless, but highly formalized." He continues "if any strange canoe passed a Chinook village and failed to stop, it was promptly pursued. If the occupants were found to be friends, or if they could prove they were bound for a friendly village on a peaceful mission, they were allowed to pass. If such were not the case, the defensive move changed to an offensive foray. ..."98 In this scenario, the Chinook pursued the various whites because they were strangers and had passed their villages, and the Indians felt their territory was threatened. And when such a disagreement among the Lower Chinook escalated to fighting, the death of one or two men on either side ended the conflict, and the party who lost the men was the loser.

shore was claimed by both the Lower Chehalis and the Chinooks proper" so it is no surprise to see these two groups acting in concert in this situation (Moulton. Journals. 6: 77).

sto Bancroft. Northwest Coast, 1800-1846. 134.

$\varsigma^{-}$ibid 
Lewis and Clark were able to avoid fighting because they were a large, heavily armed party. The Winships evaded battle because they gave in to native demands. Broughton and his men established a relationship with the Chinookans by giving gifts. But the Spanish explorers, unfortunately, fired upon the Chinook, and presumably killed some of them. They won the war, and it is no wonder the remaining Chinook would have nothing to do with them

Bishop of the Ruby had a more positive experience among the Lower Chinook. He and his crew spent most of December 1795 and January 1796 anchored in Baker Bay, just inside the mouth of the Columbia, and as a consequence had considerable dealing with the Chinook. Near the end of his stay, he writes "we have hitherto been successful in trading with the Natives and [the trade] has been conducted with the greatest Harmony their Former disposition to thieving is much abated." And how did the Ruby"s crew stem this "disposition to thieving"? "A trifling Present now and then gratifies their Desires..."When Bishop and his men began trading according to the rules, the Chinook did not need to steal from them anymore. That the relationship the Indians desired had been established is indicated in the rest of Bishop's sentence regarding presents: gifts given by the whites to the Indians were "generally returned by a Present of Fish or Cranberries, nor do they with hold their Daughters. . ."99

So, Indians exchanged gifts with one another to establish or confirm relationships, and when Lewis and Clark did not always give presents to the Lower Chinookans they

\footnotetext{
${ }_{98}^{98}$ Ray. "Lower Chinook." 59

${ }^{9 y}$ T. C. Elliot. "Journal," 267.
} 
encountered, it caused confusion and resentment. At times, Indians attempted to bring about resolution to this confusion by theft or harassment. The expedition members were also confused. To them, the Chinook were at times light-fingered and belligerent, and at other times open and cordial. They resembled the environment they lived in: unlike anything the whites had ever experienced, unpredictable, and at times out of their control. And though the explorers could not do anything about the environment, there were measures they could take to control their relationship with the Indians, like reinforce the distance between the two groups by remaining aloof. As the winter progresses, we see the captains (especially Clark) worrying less about what they could not control- the environment—and more about the Indians. 


\section{CHAPTER 4}

\section{BALANCED RECIPROCITY}

There was also much confusion between expedition members and the Lower Chinook regarding what anthropologists in general call "reciprocity," and what Sahlins refers to as "balanced reciprocity." Boyd, in his discussion of the Upper Chinookan Indians of the Wascopam Mission, gives the best description of this practice among Chinookan Indians, though his discussion centers on the upriver tribes. He writes "visiting and gift exchange ... were usual and expected ways of reinforcing social ties-both of kinship and friendship —in Plateau society. The missionaries unwittingly inserted themselves into that system and had a most difficult time adjusting to it." While Boyd is talking about the tribes and white missionaries who lived above the Cascades, he could just as well be discussing the Lower Chinook and the Lewis and Clark Expedition. And when he continues, "Indian-style visiting and reciprocity conflicted directly with American customs of privacy, private property, and selfsufficiency,"2 much of the friction between the coastal Indians and the white explorers suddenly takes on an entire new light. An examination of expedition interaction with four Lower Chinookan chiefs_Cus-ka-lah, a Clatsop; Shâh-hâr-wâr-cap, a Cathlamet;

Robert Boyd. People of the Dalles: The Indians of Wascopam Mission (Lincoln: University of Nebraska Press. 1996). 75. 
Comowool, also known as Coboway, another Clatsop; and Tâh-cum, a Chinook-will illuminate misunderstandings of this principle as they occur between the Lower Chinook and the Lewis and Clark Expedition.

\section{Clark and Cus-ka-lah}

A good example of misunderstandings regarding reciprocity between expedition members and the Lower Chinook is the interaction Clark had with the Clatsop Indian Cus-ka-lah. Clark first met this "young Chief" soon after the expedition arrived at the Fort Clatsop site. On 8 December 1805 Clark records that he "took 5 men and Set out to the Sea to find the nearest place \& make a way ... and find a place to make Salt. "The group spent a miserable night huddled around a fire in a heavy rain, with only a single elk skin for cover, and the next morning Clark sent two of the men to hunt elk and continued on to the coast with the other three. They soon found their way blocked by a "Creek which [they] could not Cross as it was deep and no wood to make a raft.

" Fortunately, they encountered three Indians who took them to their village which was located "on the See cost at a Short distance."

Here the Indians treated Clark and his men very hospitably. He writes in his Field Notes that he

was invited into a lodge by a young Chief was treated with great Politeness, we had new mats to Set on, and himself and wife produced for us to eate, fish, Lickorish, \& black roots, on neet Small mats, and Cramberries \& Sackacomey berris common to this Countrey which they gave me in a neet wooden trencher, with a Cockle Shell to eate it with.

\footnotetext{
ibid.

${ }^{3}$ Moulton. Journals. 6: 116.

${ }^{4}$ ibid. 118.
} 
when I was disposed to go to Sleep 2 neet mats was produced \& I lay on them. ${ }^{5}$

Clark's Journal Entry describes much the same scene, adding only that "all the Men of the other houses Came and Smoked with me," and "the man who' had been most attentive [was] named Cus-ka-lah."

The kind attention continued the next morning. After a stroll on the beach, Clark writes "[I] entered the Same house I Slept in, they imediately Set before me their best roots, fish and Surup." After some minor trading, Clark continues "I then Set out on my return by the Same rout $\mathbf{I}$ had Come out accompanied by Cus-ka lah and his brother as far as the ... Creek, for the purpose of Setting me across. ..." This seems to have been a very successful encounter, from both the white and Indian points of view. The Indians received a visit from their new neighbors, probably the first to that Clatsop village by any white man, and displayed extraordinary hospitality. Clark had seemingly made a powerful local friend for the whites. That he felt some bond with Cus-ka-lah is indicated by the 23 December 1805 entry mentioned above in the section on gifts given to Indians. In his Field Note entry for that day, he writes that he "Sent a Small pice of Simimon to a Sick Indian in the Town who has attached himself to me", in his Journal Entry, he identifies the recipient as Cus-ka-lah. ${ }^{8}$

\footnotetext{
${ }^{5}$ ibid.

${ }^{6}$ ibid. 119-20

ibid. 121

${ }^{8}$ ibid.. 135-36. For some reason. in the Journal Entry Clark changes the gift from a piece of cinnamon to "a little pounded fish."
} 
To this point, this seems a very cordial relationship, but things change the next day On 24 December Clark writes in his Field Notes "Cuscalar the young Clot Sop Chief Came with a young brother and 2 young squar, they gave or laid before Capt Lewis and my Self a mat and each a large Parsel of roots, Some time after he demanded 2 files for his Present we returned the present as we had no file to Speare which displeased them a little." To the captains, this was an obvious case of greed, though Clark's words "gave or laid before" suggest he was uncertain about the Indian's motives (in his Journal Entry he writes only "Iaid before"). But from Cus-ka-lah's point of view, things are different. Let us review the relationship briefly. First, Clark had visited Cuska-lah and been given gifts of food. Then, Clark had sent Cus-ka-lah a gift of food; this interchange, from the Indian point of view, had established an exchange relationship. Then Cus-ka-lah visited the whites and presented them with some food and manufactured goods, and waited a polite period for the captains to reciprocate. When they did not, he "demanded"10 something for his "present," and the captains returned his gift instead. Cus-ka-lah was probably not a little displeased, but a little confused. A relationship had been established, and now the captains were refusing to play by the rules. He had given the explorers a gift, and the customs of exchange under reciprocity required Lewis and Clark to give him one in return.

\footnotetext{
${ }^{9}$ ibid. 136.

"Clark's use of such a loaded word ( and it appears in both his Field Note and Journal Entries) is telling. How did Cus-ka-lah "demand" two files. when neither party spoke the other 's language? Did he pound his fist on the table. pull his knife out. and point at what he wanted? Or. more likely. did he simply gesture towards the tools. and then himself. indicating he would certainly appreciate owning such a valuable gift? The word "demand" is probably a combination of Clark s understanding of
} 
The Reverend Jason Lee mentions a similar, if more extreme, incident of this kind of misunderstanding regarding reciprocity among the Upper Chinook that occurred in 1843. On 3 February he writes "One [Indian] who gave us a horse came here last summer, and forcibly took a heifer from our band and drove her away. I scolded the man severely, for stealing the heifer. he would not allow that it was stealing, but only exchanging property."11 This is very reminiscent of the Cus-ka-lah situation: an Indian presented a white with a gift, and some time later-in the case of Lewis and Clark, that same day, while with Lee, six months - the Indian wants a gift in return. It is notable that on his next (and last) visit to Fort Clatsop, Cus-ka-lah did not bring gifts, but "some anchovies, Sturgeon, a beaver robe, and Some roots for Sale. ..."12 The social distance has widened, and the relationship has moved away from gift-giving to one of pure trade

\section{The Captains and Shâh-hâr-wâr-cap}

The captains' relationship with the Cathlamet chief Shâh-hâr-wâr-cap was much less strained. They first met this Indian on his 10 January 1806 visit to Fort Clatsop mentioned above in the section on gifts. In his entry for that day, Lewis writes "I gave [Shâh-hâr-wâr-cap] a medal of the smallest size; he presented me with some indian tobacco and a basquit of wappetoe, in return for which I gave hem some thread for

whatever Cus-ka-lah's method of communication was, along with an attempt to justify their returning gifts given in good faith.

${ }^{11}$ Boyd. People of the Dalles. 163

!2 Moulton. Journals. 6: 360. 
making a skiming net and a small piece of tobacco."13 This is classic reciprocity to establish a relationship at work, and while the expedition journals do not record another visit by this chief to Fort Clatsop, the explorers did meet him again on 26 March 1806 on their way back up the Columbia River. Lewis writes "we met on the way the principal Cheif of the Cathlahmahs, Sâh-hâh-wôh-cap, who had been up the river on a trading voyage. He gave us some Wappetoe and fish; we also purchased some of the latter."14 Note that Lewis differentiates between the gift and the trade, clearly indicating that at least to the Indian this was a reciprocal relationship.

This relationship was obviously more amicable than the one between the captains and Cus-ka-lah, but why is this so? One possibility is a simple clash in personalities; perhaps the explorers just did not care for the young Clatsop chief, but did like the Cathlamet Shâh-hâr-wâr-cap. But I think it had more to do with the different ways the relationships developed. Clark had been an overnight guest in Cus-ka-lah's Clatsop village, and had been given the best the Indians had. When he visited Clark at his "village," Cus-ka-lah naturally assumed he would be received in the same manner. When he was not, and was then forward enough to "demand" good treatment, bad feelings resulted.

\section{Comowool, the Captains' Favorite}

Another good example of reciprocity at work is found in the expedition interaction with the Clatsop chief Comowool, also known as Coboway, or Conia. The whites first

\footnotetext{
${ }^{13}$ ibid. 192

${ }^{14}$ ibid. 7 : 15.
} 
met him on his 12 December 1805 visit to the Fort Clatsop site discussed in the gift section above. Clark records in his Journal Entry that during that visit they gave him a medal (a small one, according to the Field Note entry) and treated him and his men "with as much attention as we could" (something Clark does not mention in relation to Cus-ka-lah). The Indians spent the night with the whites, and left the next morning after a breakfast of elk- "which they appeared to be very fond of," writes Clark-and some minor trading. ${ }^{15}$

The captains have done everything right with Comowool. He came to see them and they gave him a gift, treated him with respect, and fed him, precisely what the situation called for, from the Indian point of view. In short, although the captains may not have realized it, they had established a reciprocal relationship. That Comowool recognized this relationship is indicated by his next visit to Fort Clatsop, on 27 December 1805. Clark's Field Notes record "in the evening a Chief and 4 men Come of the Clatsop nation, Chief Co-mo wool . . ." His Journal Entry gives a clearer description of what happened next: "they presented us a root which resembles the licquirish in Size and taste, which they roste like a potato which they Call Cul ho-mo, also a black root . this root has a Sweet taste and the natives are verry fond of it . . also a dried berry about the size of a Chery which they Call Shele well. ..." And these were valuable gifts, as Clark informs us: "all those roots the Indians value highly and give them verry Spearingly." The captains reciprocated with a gift of their own, according to Clark, who writes "in return for the above roots Capt Lewis gave the Chief a Small piece of 
Sheap Skin to Ware on his head, I gave his Son a par of ear bobs and a pece of ribon, and a Small piece of brass for which they were much pleased." 16

This cordial relationship continued on 17 January 1806, when Comowool visited Fort Clatsop again. Lewis records "the Chief Comowool gave us some roots and buries for which we gave him in return a mockerson awl and some thread; the latter he wished for the purpose of making a skiming net."17 Note that there is no complaint about the reciprocal gifts here, even though Lewis hints that Comowool specifically asked for the thread. Perhaps the captains do not understand what is happening here, but are not complaining because Comowool desired something they could spare. Whatever the reason, Lewis does not seem bothered by this request.

On 6 March 1806, Comowool again visited Fort Clatsop, accompanied by "two of his children," according to Lewis. That captain continues "he presented us with some Anchovies which had been well Cured in their manner. we foud them excellent. They were very acceptable particularly at this moment. we gave the old man some small articles in return." Clark's entry supplies some more information. He writes that the children with Comowool were "Sons of his," and identifies what they gave him: "we gave the old mans Sones a twisted wire to ware about his neck, and I gave him a par of old glovs which he was much pleased with." With Comowool, the captains are participating in a reciprocal relationship. And while we don't really know why they did so with this man and not with such other visitors as Cus-ka-lah, something both

\footnotetext{
ibid. 138-39.

ibid. 214
} 
captains wrote about Comowool on this occasion may explain this: "this we have found much the most friendly and decent Indians that we have met with in this neighbourhood." day the expedition left, 22 March, when the captains gave the structure to him.

\section{Tâh-cum and Lewis' Diatribe}

The captains' 20 February 1806 account of the only visit to Fort Clatsop by Tâhcum, an important chief of the Chinook proper, illustrates yet another aspect of balanced reciprocity where expedition actions confused and insulted the Lower Chinook: the Chinookan practice of visiting. Lewis writes "This forenoon we were visited by Tâh-cum a principal Chief of the Chinnooks and 25 men of his nation. We had never seen this cheif before ... as he came on a friendly visit we gave himself and party some thing to eat and plyed them plentifully with smoke. we gave this cheif a small medal with which he seemed much gratifyed" Lewis and Clark are doing everything right here. They give food, tobacco, and gifts to an important Indian they have never met, which certainly signaled to him that a relationship was being established. But immediately following his sentence regarding gifts, Lewis writes "in the evening at sunset we desired them to depart as is our custom and closed our gates." Sergeant Gass is more frank in his description of the situation: "In the evening," he writes, "we turned out the natives as usual. . . ."20

\footnotetext{
${ }^{18}$ Moulton. Journals. 6: 38t-85.

${ }^{19}$ ibid. 330 .

2"ibid. 10:194
} 
This must have been extremely confusing and unsettling to Tâh-cum and the other Chinook. Lewis and Clark went through all the motions of establishing cordial relations, but then "Taucum and his party were hustled unceremoniously out of the fort as if they were an unwelcome set of traders selling rotten fish," to borrow Ronda's colorful description of the incident. ${ }^{21}$ Lewis obviously realized there was something unusual about this behavior, because he continues his Journal Entry under this date with a passage known among expedition historians as "Lewis' diatribe," since it is a denunciation of Native Americans in general. Lewis writes

we never suffer parties of such number to remain within the fort all night; for notwithstanding their apparent friendly disposition, their great averice and hope of plunder might induce them to be treacherous. at all events we determined allways to be on our guard as much as the nature of our situation will permit us, and never place our selves at the mercy of any savages. we well know, that the treachery of the aborigenes of America and the too great confidence of our countrymen in their sincerity and friendship, has caused the distruction of many hundreds of us. so long have our men been accustomed to a friendly intercourse with the natives, that we find it difficult to impress on their minds the necessity of always being on their guard with rispect to them. this confidence on our part, we know to be the effect of a series of uninterupted friendly intercouse, but the well known treachery of the natives by no means entitle them to such confidence, and we must check it's growth in our own minds, as well as those of our men, by recollecting ourselves, and repeating to our men, that our preservation depends on never loosing sight of this trait in their character, and being always prepared to meet it in whatever shape it may present itself. ${ }^{22}$

Clark copies this paragraph word for word in his Journal Entry.

I quote this passage in full for three reasons. First, it gives us a rare glimpse into Lewis' (and probably Clark's) mindset regarding Native Americans. Though his tone

21 Ronda. Levis and Clark. 194. 
here is rather calm and indifferent, his language is unequivocal: Lewis does not trust Indians in general, and the Lower Chinook in particular. Second, this paragraph also gives us an impression of the attitudes the enlisted men had toward Indians. Lewis seems to hint here that these men felt the captains were overcautious and extreme when it came to their dealings with the Native Americans, indicating that their relationship with the Lower Chinook may have been more amicable than the captains'. And third, this is yet another example of an expedition member exhibiting a more negative attitude about the Lower Chinook late in the Fort Clatsop winter. While it is certainly possible Lewis' true feelings had not changed, and that he was merely letting us know how he had always felt about Indians, the fact that he nowhere else allows this attitude to surface is telling. If this represents Lewis' true opinion of Indians, it took the Pacific Coast experience to induce him to record it.

Regardless of where Lewis formed these biases, his attitude as illustrated in this diatribe can help explain much of the confusion between the expedition and the Chinook. Boy writes regarding the Upper Chinook "visiting and gift exchange were usual and expected ways of reinforcing social ties," and the same seems to have been true among their cousins on the lower Columbia. ${ }^{23}$ Tâh-cum and his party came to Fort Clatsop to get acquainted, but after a pleasant visit the explorers asked them to leave, destroying, in the eyes of the Indians, any relationship that had been established.

2 Moulton. Journals. 6:331.

${ }^{2.3}$ Bord. People of the Dalles. 75. 
In short, "Fort Clatsop may have been secure that night, but closing the gates at dusk was hardly the way to impress important and powerful neighbors." ${ }^{24}$

In addition to the four instances discussed above, there were other occasions among the Lower Chinook where the idea of reciprocity caused confusion and resentment. One example of this is the captains' dislike of a Chinookan practice they considered begging. Comowool's 27 December visit to Fort Clatsop described above lasted for two days, according to Clark. In his Field notes for the $29^{\text {th }}$ he writes "the Inds. left us this morning and returned to their village, after begging for maney things which they did not secure as we Could not spare them I gave the Chief Canio a Razor. . .." Clark's Journal Entry says the Indians "left us after begging us for maney articles none of which they recvied as we Could not Spare the articles they were in most want of." 25 Lewis also comments on this aspect of Chinookan behavior when he writes on 21 February 1806 "visited this morning by 3 Clatsops who remained with us all day; they are great begers; I gave one of them a few nedles with which he appeared much gratifyed. 26

Boyd's discussion sheds some light on this subject. He writes that the whites at the Wascopam Mission experienced this same behavior among the Upper Chinook: "the missionaries found themselves besieged by Indian visitors, who came unannounced at all hours, 'begging' (the missionaries' word)." One missionary, Elvira Perkins, wrote "It would have been a strange thing for a native to pay us a visit without begging for

${ }^{24}$ Ronda. Lewis and Clark. 194.

25 Moulton. Journals. 6: 140-42 
something," and yet another white couple, Henry and Laura Brewer, were "frequent targets of native importuning." These visits became so annoying to Laura that she would lock her doors, but "the visitors would rattle them violently, rap at the windows, and perhaps shout for admittance." Once in the house, they would beg for such small items as salt, a needle and thread, meal, and various medicines. ${ }^{27}$

Such forward behavior is so strange to a white culture it is almost humorous, but to the Indians the opposite was true. Visiting was such an integral part of their culture it was inconceivable someone would not want them around. If they locked their doors, it must mean they did not know they had visitors. And according to Boyd, since the missionaries had more possessions than the Indians, they were "more often the subjects of requests." Likewise, Lewis and Clark had a variety of possessions not readily available to the Lower Chinook, and so they were often the focus of requests for such goods.

The captains also negatively comment on another aspect of Chinook reciprocitytheir habit of giving a gift, and then desiring more in return than the explorers thought it was worth. A good example of this is found in the journals on 17 November 1805, soon after the expedition arrived at their Point Ellice campsite. Lewis had been out exploring Cape Disappointment, and when he returned Clark records in his Field Notes "Several Indians followed him \& Soon after a canoe with wapto roots \& Lickorish boiled, which they gave as presents, in return for which we gave more than the worth

\footnotetext{
2t ibid. 333.

2 Boyd. People of the Dalles, 75
} 
to Satisfy them a bad practice to receive a present of Indians, as they are never Satisfied in return." ${ }^{28}$ In his Journal Entry, Clark gives us more information, and also passes some interesting value judgments, again illustrating how his attitudes changed over the course of the Fort Clatsop winter. He writes "Several Chinnook Indians followed Capt L- and a Canoe came up with roots mats \&c. to Sell. Those Chinnooks made us a present of a rute boiled much resembling the common liquorice in tast and Size: in return for this root we gave more than double the value to Satisfy their craveing dispostn." While Clark does not tell us how the expedition knew what the local going price for boiled root was, he does tell us how he felt about the local exchange customs when he writes "it is a bad practice to receive a present from those Indians as they are never Satisfied for what they $r[e c] e i v e$ in return if ten time the value of the articles they gave. ${ }^{, 29}$

The captains would agree with Reverend Lee's portrayal of the Upper Chinook on this subject: "I am fully satisfied, that all gifts of Indians are emphatically Indian gifts, That they, invariably, expect, and are not satisfied unless they receive more value than they give, where they make a present. ${ }^{, 30}$ Lee could be paraphrasing the captains' statements, and from the white point of view, the Indians were greedy. But this is yet another aspect of balanced reciprocity, and this brings us to that part of exchange known as trade, and to Pryor's scheme of market exchange among primitive peoples.

\footnotetext{
${ }^{28}$ Moulton. Journals. 6:60. The boiled root was seashore lupine. according to Moulton's note on page 61

29 ibid. 61

${ }^{30}$ Boyd. People of the Dalles. 163.
} 


\section{CHAPTER 5}

\section{THE LOWER COLUMBIA MARKET SOCIETY}

According to Pryor, among indigenous peoples "exchange transactions can be arranged along a continuum defined according to the visibility of supply and demand forces." At one end, he describes "reciprocal exchange where supply and demand forces are suppressed and other forces manifest themselves"- this would be analogous to Sahlins" "Generalized Reciprocity," or "pure gift." But at the other end of the continuum, Pryor describes "market exchange, where ... economic forces are highly visible." This kind of exchange was prevalent among the Lower Chinook in their trade methods.

Next to stealing, the captains had more negative things to say about Lower Chinookan trade practices than any other thing. They had limited trade goods, and needed to stretch those goods far enough to both survive the winter and make their way back east. As a result, they considered the Chinook "sharp traders bent on gouging the needy."2 They came to this conclusion soon after they reached the coast, as is indicated by the many early references to the "high prices" the Indians wanted for their goods. For example, on 21 November 1805, Clark records a visit to their Point

\footnotetext{
'Pryor. Origins of the Economy. 31

2 Ronda. Lewis and Clark. 179.
} 
Ellice campsite by a group of the Chinook proper, and writes in his Field Notes "we bought roots... Some mats \&c. \&c. for which we were obliged to give emence prices." And on 23 November 1805, while the party was still in the same location, Clark writes that seven Clatsop Indians crossed the river bringing " 2 orter Skins, for which they asked Such high prices we were uneabled to purchase. . ."4 Just three days later, after the party had crossed to the south side of the river, they visited a village of Cathlamet Indians and, Clark writes in his Field Notes, bought some wapato roots at "a high price." "The people of the last village," noted Clark at their campsite that night, ". . . ask emence prices for what they have to Sel." The next morning, Clark tells us that when these same Indians visited the expedition "with roots meat, Skins \&c. to Sill, they asked Such high prices we were unable to purchase anything.

$"$ There are also numerous other such references. ${ }^{6}$

From the expedition viewpoint, this was simple greed. Clark's Journal Entry on 12 December is classic: "I can readily discover that they are Close deelers, \& Stickle for a verry little, never close a bargin except they think they have the advantage." echoes this statement on 20 December, when he writes in his Field Notes, "Those people ask double \& tribble the value of everry thing they have to Sell, and never take less than the full value of any thing. . . $" 8$ And when Lewis begins writing in January 1806, it doesn't take him long to record how he feels about Chinookan trading

\footnotetext{
${ }^{3}$ Moulton. Journals, 6: 74 .

${ }^{4}$ ibid. 81 .

ibid. 87-88.

"ibid. 90. For other examples. see pages 124, 145, 146. 358-59.
} 
practices. He writes "they are great higlers in trade and if they conceive you anxious to purchase will be a whole day bargaining for a handfull of roots." To this description, Lewis appends his opinion on why they Chinook are such hard bargainers: "I therefore believe this trait in the character proceeds from an avaricious all grasping disposition."

But before we take such a damning description at face value, there are two other things to consider. First, how did Lewis and Clark know what the going rates for various items were? When Clark writes that the Chinook "are never Satisfied for what they re[ce]ive in return if ten time the value of the articles they gave," some knowledge of relative values. Second, we need to consider the Chinookan point of view, asking how they felt about the subject.

Neither captain tells us the basis for their assumptions about prices on the lower Columbia, but there were probably two things: first, the reports of earlier explorers and traders in the region; and second, their experiences with tribes higher up the Columbia. The Northwest fur trade had its roots in the 1778 visit by Captain James Cook to the region. After he was killed in Hawaii, his two ships visited Canton in China and sold otter pelts obtained on the Pacific Coast for a huge profit, and Captain James King, who had taken command after Cook's death, described the commercial possibilities of the region in a work published in 1784. An American named John Ledyard had accompanied the Cook expedition, and he also described the large profits to be made in

ibid. 123

8 ibid. 134

ibid. 164

ibid. 61 . 
the Pacific fur trade. These reports were widely published, and traders were soon on the coast "bartering trinkets, textiles, metals and weapons for various furs, primarily sea otters." 11

It is certain that at least Lewis had also read Vancouver's account of his explorations in the Pacific Northwest, ${ }^{12}$ including how he had sent a ship from his squadron (the Chatham, under Broughton) up the river in 1792. An extensive summary of Broughton's report to him was included in his Voyages, which had been published in 1798. This account describes trading with the Indians, and while no specific trade items are mentioned, neither is there any complaint of high prices. Indeed. Vancouver reports that Broughton said "by keeping upon good terms with the natives, who seemed much inclined to be friendly, a supply of fish, and other refreshments, may easily be obtained."13 The captains probably expected the Lower Chinook they encountered in 1805 and 1806 to have the same set of relative values, or desire for European goods, that they did when Broughton met them in 1792, but they had had much contact with traders since then, and they were canny enough traders to recognize that they could get more for their goods. In Ronda's words, "The Chinookans were convinced, at least by 1805 , that whites would eventually pay any price for sea otter pelts."14

\footnotetext{
"James R. Gibson. "Bostonians and Muscorites on the Northwest Coast. 1788-1841." in The IIestern Shore: Oregon Country Essavs Honoring the American Revolution, edited by Thomas Vaughan (Portland. Oregon: Durham \& Downey. 1975), 82-86.

: See Jackson. Letters. 13n. 53.

${ }^{13}$ Vancouver. Ioyage of Discovery. 769.

${ }^{14}$ Ronda. Lewis and Clark. 184.
} 
That the Indians on the Columbia River raised the price of their goods is documented in the accounts of early traders on the river. In September of 1793 a small schooner named the Resolution traded with the Lower Chinook and "procured 63 otter skins and 27 clamons, which was purchased with only copper and cloth, iron being in no demand."15 Less than a year earlier, Edward Bell (with Broughton in the Chatham) described an Indian attempt to steal an "Iron Stantion," indicated that metal still had some value at that time ${ }^{16}$ Boit's account of the first trading ship to enter the riverthe Columbia-says the Lower Chinook traded salmon to the whites for nails, and "Beaver Skins [for] 2 Spikes each, and other land furs, 1 Spike each." Boit does state the Indians would only trade otter skins for copper, but even so, in 1792 iron did have some value among the Lower Chinook. ${ }^{17}$ And Bishop of the Ruby, regarding his trading experience on the lower Columbia, writes that their furs were "not bought so cheap as they have been at this place," indicating that the natives had raised their prices. ${ }^{18}$ It is likely that Lewis and Clark relied on the reports of early explorers and traders for information regarding native value of their goods, and that the many traders working on the coast had driven the prices higher.

\footnotetext{
${ }^{15}$ F. W. Howay: "The Resolution on the Oregon Coast. 1793-1794." Oregon Historical Quarterly 34 (September 1933): 209.

${ }^{16}$ J. Neilson Barry: "Columbia River Exploration. 1792." Oregon Historical Quarterly 33 (March 1932): 39.

${ }^{-}$Meany. "New Log." 33. Iron was still in demand at Gravs Bay, just north of the Columbia River. in 1788. In Haswell's log of the sloop Washington we read "two canoes with four people in each came alongside we purchased several sea otter skins of them at a very reasonable rate for iron ..." See $T$. C. Elliot. "Captain Robert Gray `s First Visit to Oregon." Oregon Historical Quarterly 29 (June 1928): 179.

${ }^{18}$ Elliot. "Journal." 263
} 
The explorers also found relative prices to be much lower among the Indians of the interior than those they encountered on the coast. On 21 October 1805, when the expedition visited some Salishan-speaking peoples just above Celilo Falls, Whitehouse notes "they gave us any thing we asked for by our giving any Small article we pleased." And while Clark does not mention this incident (we have no journal from Lewis at this time), Ordway's entry is nearly identical to Whitehouse's. ${ }^{20}$ The captains really had no way of knowing what the going rate for goods was on the Lower Columbia, so they relied on past experience, both their own and that of others.

The other thing to consider in this context is the position of trade in the lives of the Lower Chinook. According to Ray, "a thorough-going occupation with commerce dominated Chinook life." He points out that the Lower Chinook were at the center of "three great streams of travel": first, from the north along the coast; second, from the south along the coast; and third, from the interior along the Columbia River. This central location solidified their position as middlemen in trade, and contributed to their feeling that "trade was an end in itself." 21

Clark would agree with this last assessment. After the 12 December 1805 visit to Fort Clatsop by Comowool, he writes in his Field Notes regarding the natives "they are tite Deelers, value Blu \& white beeds verry highly, and Sell their roots also highly. ..." His Journal Entry is more to the point: "I can readily discover that they are Close

\footnotetext{
${ }^{19}$ Moulton. Journals. 11:362-63.

" ibid. 9: 242 . Ordway adds "as if they were in fear of us" to the statement. giving another possible reason the Indians sold their goods for low prices.

"Ray. "Lower Chinook." 99.
} 
deelers, \& Stickle for a verry little, never close a bargin except they think they have the advantage. ${ }^{, 22}$ And one of Lewis' first entries after he resumed writing on 1 January 1806 also comments on this. On 4 January he writes regarding the "Chinnooks and other residing" on the lower Columbia that

they are great higlers in trade and if they conceive you anxious to purchase will be a whole day bargaining for a handfull of roots; this I should have thought proceeded from their want of knowledge of the comparitive value of articles of merchandize and the fear of being cheated, did I not find that they invariably refuse the price first offered them and afterwards very frequently accept a smaller quantity of the same article. ... ${ }^{23}$

For the Chinook, "Trading [had become] a ritual game enjoyed as much for sport as for material reward," to quote Ronda. ${ }^{24}$

In this same entry, Lewis records an interesting anecdote from his experience dealing with Lower Chinookan trade practices. Regarding the idea that the Chinook would eventually take less value for an article than first offered, he writes

in order to satisfy myself on this subject I once offered a Chinnook my watch two knives and a considerable quantity of beads for a small inferior sea Otter's skin which I did not want, he immediately conceived it of great value, and refused to barter except I would double the quantity of beads; the next day with a great deal of importunity on his part 1 received the skin in exchange for a few strans of the same beads he had refused the day before.

Lewis also answers the "why" in this passage, writing "I therefore believe this trait in their character proceeds from an avaricious all grasping disposition. ${ }^{25}$ But Chinookan

\footnotetext{
22 Moulton. Journals. 6: 123 .

23 ibid. 165 .

${ }^{2-4}$ Ronda. Lewis and Clark. 184
} 
trade practices were not the product of some basic character flaw, but a way of life. That this preoccupation with trade and desire for gain was deeply ingrained among the Chinook is evident from an early Clatsop text, recorded by Franz Boas, which describes the first ship to founder near the Columbia River. It notes that after the white sailors burned the boat, "the Clatsop gathered the iron, the copper, and the brass" and exchanged these metal items to the neighboring tribes. "The people bought this," the tale says, "and the Clatsop became rich." ${ }^{26}$ In Ronda's words, "Trade and the acquisition of material wealth had always been an important part of Chinookan life. ${ }^{.27}$

The Captains used their negative perceptions of this aspect of Lower Chinookan life as an excuse, along with the Clatsop theft of elk killed by Drouillard discussed above, for the action Ronda calls "a particularly sordid tale of deception and friendship betrayed ${ }^{\prime 28}$ - the notorious theft of a Clatsop Canoe by expedition members. Since this episode illustrates both the expedition and Indian viewpoints on the lower Columbian market economy, I will examine it in detail.

\section{The Expedition, the Chinook, and the Canoe: Different Conceptions of Trade}

Lewis and Clark knew they would need good canoes for their upriver trip, and so on March $13^{\text {th }}$ they "sent Drewyer down to the Clatsop village to purchase a couple of

\footnotetext{
${ }^{25}$ Moulton. Journals, 6: 165. I should note that Clark, as was his custom after 1 January. copies this entry nearly word for word. only he ascribes the event to himself. And when he composed his Journal Entry for 22 November. describing events when the expedition was still camped below Point Ellice. he (with some minor changes) also inserted this anecdote there, again ascribing the actions to himself.

${ }^{26}$ Franz Boas. Chinook Texts (Washington. D. C.: Government Printing Office. 1894). 278.

2 Ronda. Lewis and Clark. 188.

${ }^{28}$ ibid. 210 .
} 
their canoes if possible."29 The next day "late in the evening Drewyer arrived with a party of the Clatsops who brought a indifferent canoe ... but [we] could not obtain the canoe without giving more than our stock of merchandize would lisence us." Lewis records he even "offered [the canoe's owner] my laced uniform coat but he would not exchange. ${ }^{{ }^{30}}$ Clark adds a typical judgment to his version of the incident in his Journal Entry: "agreeable to their usial way of trading his price was double."

Word of the company's need for a canoe must have spread very rapidly, because on the $15^{\text {th }}$ of March Lewis writes "late this evening we were also visited by Catel a Clatsop man and his family. He brought a canoe and a Sea Otter Skin for sale neither of which we purchased. ..,32 Finally, on March $17^{\text {th }}$ Lewis writes "Drewyer returned late this evening from the Cathlahmahs with ... a canoe which he had purchased from those people. for this canoe he gave my uniform laced coat and nearly half a carrot of tobacco ${ }^{n-1}$ - the expedition had obtained an Indian canoe, but at what they considered a great cost

The high price they had to pay for the single canoe led them to adopt a different method for obtaining a second one. On March $17^{\text {th }}$, Lewis writes "we yet want another canoe, and as the Clatsops will not sell us one at a price which we can afford to give we will take one from them in lieu of the six Elk which they stole from us in the

\footnotetext{
${ }^{24}$ Moulton. Journals. 6: 409 .

${ }^{30}$ ibid. 414

${ }^{31}$ ibid. 416

32 ibid. Clark writes "neither of which we could purchase of him" (ibid. 418).

${ }^{33}$ ibid. 426.
} 
winter." ${ }^{34}$ Clark's entry for that day gives us a little more information: "We yet want another Canoe as the Clatsops will not Sell us one, a proposition has been made by one of our interpt and Sever[al] of the party to take one in lieu of the 6 Elk which they Stole from us this winter \#c. ${ }^{335}$ This is the last mention of the matter by Lewis and Clark, but Sergeant Ordway notes in his entry for the next day (18 March 1806) that "4 men went over to the prarie near the coast to take a canoe which belongd to the Clatsop Indians, as we are in want of it." ${ }^{36}$

This is a very sticky issue, one that troubles students of the Lewis and Clark expedition. Ronda calls this episode "at worst criminal and at best a terrible lapse of judgment, ${ }^{377}$ while Lavender takes a softer tone: "a question of relative ethics arises: how desperate do you have to be to resort to pilfering from a friend who demands more for what you must have than you are able to pay?"38 I do not want to pass judgment on either the whites or the Chinook here. What I will do is use this episode to illustrate the differing positions of the two groups on this aspect of trade. This examination will portray very well the differing mindsets of the two groups, and once again show us how these different ideas led to misunderstandings, mistrust, and dislike

The expedition point of view is quite simple. Lewis says they needed a canoe and tried to purchase one, but the Indians would not trade at a reasonable price. And though Ronda writes that "expedition goods were in short supply, but experience

\footnotetext{
${ }^{34}$ ibid.

35 ibid. 428

${ }^{36}$ ibid. $9: 278$

$3^{-}$Ronda. Lewis and Clark. 211.
} 
always proved that patience in coastal trade usually yielded a satisfactory exchange," the evidence in the journals does not support this view. ${ }^{39}$ Both Lewis and Clark note several occasions when party members simply could not afford to purchase the goods Indians offered them. For example, on 20 December 1805 Clark writes " 3 Indians came with Lickorish Sackacomie berries \& mats to Sell, for which they asked Such high prices that we did not purchase any of them." ${ }^{, 40}$ And on 17 January, Lewis writes "This morning we were visited by Comowool and 7 of the Clatsops our nearest neighbours... They brought with them some roots and berries for sale, of which however they disposed of but very few as they asked for them such high prices as our stock in trade would not license us in giving." ${ }^{.41}$

In addition, on 1 February (nearly two months before the party left Fort Clatsop) Lewis writes a long description of various types of Indian canoes, and then notes "we have been anxious to obtain some of them, for our journey up the river but have not been able to obtain one as yet from the natives in this neighbourhood. ${ }^{, 42}$ Apparently the captains had begun trying to purchase a canoe long before their departure date, but in this case "patience" did not yield a "satisfactory exchange." From this evidence, it would seem the party was justified in their actions. They needed a canoe, and the Clatsops would not sell one at a rate the whites could afford, and the Indians had often

\footnotetext{
${ }^{38}$ Lavender. Hestern Sea. 314.

${ }^{39}$ Ronda. Lewis and Clark. 211. Ronda himself doesn't seem totally convinced by his argument here: note how in this sentence the absolute "always" is softened immediately by the adierb "usually."

${ }^{410}$ Moulton. Journals, 6: 133.

${ }^{41}$ ibid. 214. For further examples see Moulton. Journals, 6: 81, 85, 90, 124. 145, 146. 358-9.

A2 ibid. 265.
} 
stolen from the explorers. The solution? Take one. But let us now consider the Chinookan point of view.

To understand how the Indians felt about this subject we need to consider two things. First of all, how highly did they value their canoes? How much labor did it take to make one, or how much did it cost to purchase one? The second thing is related to the first: were the prices Lewis and Clark offered to the Indians for their canoes commensurate with their value? And as always, Clark's pejorative comments, usually written after the fact, need to be noted.

The Lower Chinook used several different kinds of canoes, and while it is difficult to differentiate between the types, ${ }^{43}$ Lewis and Clark described "four forms of canoe only in uce among the nations below the grand chatarac" of the Columbia River. The largest of these were "upwards of 50 feet long and will carry from 8 to 10 thousand lbs.," while the smallest were "about 15 feet long and calculated for one or two persons. ${ }^{.44}$ These were universally described in positive terms by explorers and traders who visited the Columbia River. Lewis wrote "the natives inhabiting the lower portion of the Columbia River make their canoes remarkably neat light and well addapted for riding high waves, ${ }^{, 45}$ and Robert Stuart is even more unrestrained in his admiration of

\footnotetext{
${ }^{43}$ Ray: "Lower Chinook," 103. Ray recognizes five types, though he admits that distinctions are difficult to make. Olson only identifies three types, and feels that any distinctions beyond what he recognizes are based more on size than type. See Ronald L. Olson. "Adze, Canoe. and House Types of the Northwest Coast." Linversity of Washington Publications in Anthropology 2 (November 1927): 19

${ }^{14}$ Moulton. Journals. 6: 263

45 ibid. 262
} 
these vessels: "If perfect symmetry, smoothness, and proportion constitute beauty, they surpass anything I ever beheld. ... .

It was not easy to make these canoes. Lewis recognizes the difficulty, writing that the only tool used was "a chissel formed of an old file," but then notes "a person would suppose that the forming of a large canoe with an instrument like this was the work of several years; but these people make them in a few weeks. ${ }^{947}$ However, James Swan, who lived among the Chinook on Willapa Bay during the early 1850s, tempers this optimistic time estimate. His description of the process is relevant enough to quote at length:

The manufacture of a canoe is a work of great moment with these Indians. It is not every man among them that can make a canoe. . . A suitable tree is first selected, which in all cases is the cedar, and then cut down. ... [and] stripped of its bark, then cut off into the desired length, and the upper part split off with little wedges.

After the log has been hewn "into a rough shape," the Indian craftsman goes to work to "fashion it out." The outside is formed to the desired shape, and then the inside is "cut out with the axe. This operation was formerly done by fire, but the process was slow and tedious." When the inside and outside were both finally finished, the canoe was painted red and black. Swan ends his description by noting that the canoe construction he describes took place near his house, and he "saw the progress every day, from the

\footnotetext{
15tuart. Discovery of the Oregon Trail. 14.

$4^{-}$Moulton. Journals, 6: 265.
} 
time the tree was cut down till the canoe was finished. This was a medium sized canoe, and took three months. ..."48

It is easy to explain away the discrepancy in time estimates between Lewis and Swan by hypothesizing that the former describes the construction of a small canoe, while Swan specifically says the one he observed being built was "medium sized." And we know that neither describes the process of forming one of the largest, because these canoes were not made on the lower Columbia, but purchased from Indians living on Vancouver Island. ${ }^{49}$ But whether the canoes the expedition attempted to purchase from the Lower Chinook took a few weeks or three months to form, or were procured from the more northerly Indians, the reason they would not easily part with them is apparent-they had much invested in their acquisition or construction. It was no wonder that "they prize[d] their canoes very highly."

The captains themselves tell us how highly the Lower Chinook valued their canoes, and when we consider what they said regarding this, it is no surprise they found the price dear. After noting that Drouillard had traded his uniform coat and some tobacco to the Cathlamets for a single canoe (no information on its size), Lewis writes "it seems that nothing except this coat would induce them to dispose of a canoe which in their mode of traffic is an article of the greatest val[u]e except a wife, with whom it is equal,

\footnotetext{
${ }^{48}$ James Swan. The Vorthwest Coast, Or, Three Years' Residence in Washington Territory (Seattle: University of Washington Press. 1972. 80-82.

${ }^{19}$ Ruby and Brown. Chinook Indians. 18

Moulton. Journals. 6: 265
} 
and is generally giving in exchange to the father for his daughter." ${ }^{.51}$ Just how much value a wife could have among the Lower Chinook is recorded by Bishop of the Ruby, who says the price an Indian paid the Chinook chief Shelathwell for one of his daughters was "twenty Slaves twenty Sea otter Skins a Cannoe and twenty leather War Dresses. ..." "52 Even when we take into account Ray's observation that in Chinookan marriages, "the amount of goods transferred [from the groom to the bride's family] was a direct reflection of the family's social position, ${ }^{, 53}$ this puts a high value on wives and, by extension from Lewis' entry, canoes. In the words of Albert Lewis, "canoes formed an important part of [Chinookan] property. 154

In general, the explorers considered the Lower Chinook price-gouging opportunists, and felt they were inconsistent, hard driving, and unpredictable in their exchange practices. From the captains' viewpoint, the coastal Indians were habitual thieves, demanded more for their goods than they were worth, and were never satisfied with what the explorers gave them in exchange. But from the Indians' perspective, the thefts were often justified, either to force the white explorers to take notice of them, or as compensation for resources the expedition appropriated. And trade had always been important to them. Ray notes that "a thorough-going occupation with commerce dominated Chinook life,"55 and though this characteristic made the Indians very unattractive to expedition members, trading and gift giving were such integral parts of

\footnotetext{
${ }^{51}$ ibid. 426

${ }^{52}$ Elliott. "Journal." 277.

${ }^{53}$ Rav. "Lower Chinook." 72.
} 
their lives and culture that when the whites did not act according to what custom required, the natives were often confused.

The whites were also confused. Clark could not understand why the Chinook constantly pilfered from the expedition, and so labeled them "theivishly inclined." Lewis could not understand why the Indians would refuse to trade an item one day, and then give up the same thing the next day for a lower price; he attributed this to an "avaricious all grasping disposition." 56 And this uncertainty about their neighborstheir customs, motives, and intentions-led to unease and dislike. Just as the environment was completely beyond anything the explorers had ever experienced, so the practices of the natives living in that environment were strange and unknown. As with the environment, the captains felt that they had lost control of the situation, and this contributed to a very unpleasant winter. And we will see this same fear of what is foreign in the next chapter, on the customs and appearance of the Lower Chinook.

\footnotetext{
${ }^{54}$ Albert Buell Lewis. "Tribes of the Columbia Valley and the Coast of Washington and Oregon," Memoirs of the American Anthropological Association 1 (1905-1907): 163.

${ }_{55}$ Rar. "Lower Chinook." 99.

${ }^{56}$ Moulton. Journals. 6: 165 .
} 


\section{CHAPTER 6}

\section{CHINOOKAN CUSTOMS AND APPEARANCE}

Most of the early writers who visited the Lower Chinook describe their physical appearance in positive terms. In 1792, John Boit of the Columbia wrote "the men, at Columbia's River, are strait limb'd, fine looking fellows, and the Women are very pretty." A year later, the Spaniard Zayas described them as "corpulent, strong people of good appearance." Bishop, of the Ruby, recorded in 1795 that "the men are commonly below the middle size, but active and strong, the Women are shorter, and all of them full and lusty about the Waist." The Astorian Robert Stuart wrote in 1812 that "they have very round faces, with small animated eyes, a broad flat nose, a handsome mouth, even and white teeth, well shaped legs and small flat feet." Swan, in the 1850s, said "the Indians north of the Columbia are, for the most part, good-looking, robust men, some of them having fine, symmetrical forms." And, he continues, though "they have been represented as diminutive, with crooked legs and uncouth features," this is not an accurate portrayal: "as a general rule, the direct reverse is the truth."

\footnotetext{
'Meany: "New Log." 35

"Wagner. "Last Spanish Exploration," 327.

${ }^{3}$ Elliot. "Journal." 276

4 Stuart. Discovery of the Oregon Trail. 12.

${ }^{5}$ Swan. Vorthwest Coast. 154.
} 
But according to historians of the Lewis and Clark expedition, those explorers did not especially care for the customs and appearance of the Lower Chinook. Bernard DeVoto, drawing his information from expedition journals, said the Indians at the mouth of the Columbia were "decadent," "declining culturally," and "a wretched lot," ${ }^{\text {, }}$ and that Chinookan visits to Fort Clatsop soon became "tiresome" to the explorers. ${ }^{9}$ Lavender hints that the whites found such Chinookan customs as ankle binding, tattooing, and head flattening unattractive, as does Ronda, who writes that expedition members "found many Chinookan customs and practices both incomprehensible and reprehensible." Ronda continues "every culture promotes its own image of an attractive body. The Indians of the Northern plains came quite close to the somatic norm held by the explorers. But the Indians Lewis and Clark found on the lower Columbia and on the coast did not fit the Euro-American image."10 Stephen Ambrose simply writes "the natives [living on the lower Columbia] made a poor impression on Lewis and his party. ..."11 And these comments do often reflect the explorers' writings, who at times described the coastal Indians as "ugly," "squat," and "dirty," and wrote slightly negative descriptions of Chinookan practices like head flattening, ankle binding, and tattooing.

\footnotetext{
${ }^{6}$ Bernard DeVoto. The Journals of Lewis and Clark (Boston: The Houghton Mifflin Company, 1953). 293.

ibid. 298.

${ }^{8}$ ibid. 336.

${ }^{9}$ ibid. 312 .

${ }^{16}$ Lavender. Hestern Sea. 295: Ronda. Lewis and Clark, 179.

${ }^{11}$ Stephen E. Ambrose, Lindaunted Courage: Meriwether Lewis, Thomas Jefferson, and the Opening of the American II est (New York: Simon \& Schuster. 1996). 303.
} 
But what the historians of the Lewis and Clark expedition do not usually note is that those explorers also left us with positive, or at least neutral, descriptions of the Lower Chinook and their practices, and often these entries in expedition journals echo the sentiments of the other early white visitors to the lower Columbia. ${ }^{12}$ We have both positive and negative descriptions of the physical appearance of the coastal Indians by Lewis and Clark and their men, and rather neutral portrayals of their customs. But, these contradictions can be explained by an examination of each expedition account of Lower Chinookan custom and appearance

\section{Tattooing and Ankle Binding}

On 21 November 1805, Clark first records his impressions of tattooing and ankle binding. He writes in his Field Notes "I saw the name of J. Bowmon marked or picked on a young Squars left arm. The women of this nation Pick their legs in different figures as an orniment." Regarding ankle binding, he merely states "the women ware a String of Something curious tide tight above the anckle, all have large Swelled legs \& thighs." ${ }^{\prime 3}$ His Journal Entry gives us a little more information on ankle binding:

the womin of the Chinnook Nation have handsom faces low and badly made with large legs $\&$ thighs which are generally Swelled from a Stopage of the circulation in the feet (which are Small) by maney Strands of Beeds or curious Strings which are drawn tight around the leg above the anckle... ${ }^{14}$

\footnotetext{
:" Ronda does note that "practices such as head flattening and ankle binding ... were given remarkably value-free descriptions in the journals" (Lewis and Clark. $283 \mathrm{n} 38$ ).

${ }^{13}$ Moulton. Journals. 6: 74.

${ }^{14}$ ibid. 75
} 
Clark's entries describing these practices, while illuminating and detailed, are hardly negative

Lewis' only entry regarding these practices is similar. On 19 March 1806 , during a long, impartial description of Lower Chinookan dress and customs, he states regarding ankle binding "the large or apparently swolen legs particularly observable in the women are obtained in a great measure by tying a cord tight around the ankle."15 Concerning tattooing he writes "these people seldom mark their skins by puncturing and introducing a colouring matter such of them as do mark themselves in this manner prefer their legs and arms on which they imprint parallel lines of dots either longitudinally or circularly. the women more frequently than the men mark themselves in this manner." ${ }^{\prime 16}$ Finally, Clark apparently mentioned ankle binding to Biddle, because Biddle wrote "Tie tight their ankles to make legs swell. Chinooks \& Clatsop women ${ }^{n-17}$

These statements are quite neutral, and it does not seem either captain is contemptuous of either tattooing or ankle binding, and Clark even gives us the reason the Lower Chinook did this to their legs. In his 21 November entry he writes "those [practices] are Considered by the native of this quarter as handsom deckerations, and a woman without those deckorations is Considered as among the lower Class." ${ }^{.18}$ So, the

\footnotetext{
${ }^{15}$ ibid. 433.

${ }^{16}$ ibid. +35 .

$1-$ Jackson. Letters. 2: 503 .

${ }^{18}$ Moulton. Journals. 6: 75
} 
captains recognized the cultural significance of these practices, and did not comment negatively on them in their journals or anywhere else.

\section{Head Deformation}

The captains' statements about the western Indians' practice of head flattening in their journals follow a similar pattern. The first reference to Indian head flattening appears in Clark's entry for 17 October 1805 . The party was in the area where the Yakima River empties into the Columbia, and Clark gives a description of the local women, which in part reads "those women ... [have a] low Stature broad faces, heads flatened and the forward compressed so as to form a Streight line from the nose to the Crown of the head ..."19 But since this is in his Journal Entry, and there is no corresponding passage in his Field Notes, we must look to his entries ten days later for a true first impression. The explorers had arrived at The Dalles Rapids on the $26^{\text {th }}$, and camped among the Indians there for a couple of days. Clark writes in his Field Notes on the $27^{\text {th }}$ "above, all flatten the heads of their female children near the falls, and maney above follow the Same Custom." His Journal Entry explains this confusing sentence: "all the Bands flatten the heads of the female Children, and maney of the male children also. ${ }^{, 20}$

The next reference is when the party was at the Cascades, midway between the Dalles and modern Portland, Oregon. Clark writes "all the women have flat heads pressed to almost a point at top The press the female childrens heads between 2

${ }^{19}$ ibid. 5: 289 . 
bords when young-until they form the Skul as they wish it which is generally verry flat. This amongst those people is considered as a great mark of buty."21 And these comments about Upper Chinookan head deformation practices were matched by statements regarding this custom among the Lower Chinook. On 4 November, as the expedition passed villages just below modern Portland and Vancouver, Clark wrote cryptically in his Field Notes "those people men \& women heads are flat.",2 And though he later copies Lewis' description of this practice, his own record of the process in the journal ends on the first pages of his notebook journal Voorhis No. 2, immediately preceding his 30 January 1806 Journal Entry, where he gives us some sketches and notes relating to this practice. ${ }^{23}$ Clark's comments are not really negative to this point Rather, he is merely describing the customs he is seeing among the Lower Chinook, and this is what Lewis does when he finally describes head flattening

In Lewis' 19 March 1806 general description of the Lower Chinook mentioned above, he describes head flattening in detail, and his passage is informative enough to quote in full:

the most remarkable trait in their physiognomy is the peculiar flatness and width of forehead which they artificially obtain by compressing the head between two boards while in a state of infancy and from which it never afterwards perfectly recovers. this is a custom among all the nations we have met with West of the Rocky mountains. I have observed the heads of many infants, after this singular bandage has been dismissed, or about the age of 10 or eleven months, that were not more than two inches thick about the upper edge of the forehead and reather

\footnotetext{
20 ibid. 345 .

21 ibid. 369.

22 ibid. 6: 15

23 ibid. 252
} 
thiner still higher. from the top of the head to the extremity of the nose is one streight line. this is done in order to give a greater width to the forehead, which they much admire. this process seems to be continued longer with their female children than their mail children, and neither appear to suffer any pain from the operation. ${ }^{24}$

Lewis, like Clark, is not explicitly critical of this practice in his discussion, but when he writes immediately following this passage that a child subjected to this process "never afterwards perfectly recovers," there could be an implied criticism. Does he mean the child never recovers its natural physical shape, or does he mean "never recovers" in a more generally negative way?

Clark, in his discussions with Nicolas Biddle in 1810, was openly critical of this native custom, telling him bluntly at one point "children die under the operation of head flattening. "25 $\mathrm{He}$ also informed Biddle that "almost all the people whom we saw west of the Ry. Mounts. Flatten their heads more or less. The Chopunniesh nation \& Shoshonees confine the practice to the women, but it extends to many of the men even as we approach the falls \& below that universal." And he perceives another sinister result of this practice. Biddle records that Clark told him "the Flatheads were a much inferior race to those where the practice did not prevail—understanding, [and] all the qualities, ${ }^{, 26}$ implying that the process interfered with normal cognitive operations. So, to Lewis and (especially) Clark, head deforming was both unsightly and unhealthy. But to the Chinook, this practice was something altogether different.

\footnotetext{
${ }^{24}$ ibid. 433 .

25 Jackson. Letters. 2: 506 .

${ }^{2}$ ibid. 545 .
} 
Among the Lower Chinook, head flattening was considered "the badge of aristocracy," according to Kate Juhrs, a full-blooded Clatsop Indian reminiscing in 1936. She continues "none but the free members of the tribe were permitted to flatten the heads of their children., 27 "In fact," write Ruby and Brown, "on raids these people did not enslave those with flattened heads. ${ }^{28}$ This information corresponds to a statement by Silas B. Smith, a grandson of the Clatsop Chief Comowool/Coboway the captains thought so highly of. He writes "within the limits of their [those who practice head flattening] territory no person having a flattened head was ever held as a slave." And Smith also comments on head flattening as a sign of superior status: "intermarriages between flatheads and nonflatheads were indulged in to a limited extent only. $" 29$

Smith also has a rebuttal to the notion that this practice blunted the intellect of people who had undergone this process. He writes "the facts in the case, I think, hardly warrant this conclusion. They certainly compare favorably with any of the other Indians inhabiting the old Oregon country in things pertaining to the affairs of life." For proof of this, he offers the following examples: their board dwellings, which he considers "better houses for their habitations that the teepees used by those east of the Cascade Mountains"; "their canoes," which "for beauty of model, finish of workmanship, and for utility, were far superior to anything in that line made by the

\footnotetext{
2- Emma Gene Miller. Clatsop County, Oregon: Its History, Legends, and Industries (Portland. Oregon: Binford \& Mort. 1958), 60..

${ }^{2}$ Ruby and Brown. Chinook Indians. 47. Slaves and slave trading were very important in Lower Chinookan life: see Ray. "Lower Chinook," 51-54.
} 
inland people"; and "their methods of catching fish."30 James Swan also refutes the idea that head deformation negatively affected Indian intelligence, when he writes "I never perceived that it affected the mind at all, although it disfigures [the Indians] very much in appearance. ${ }^{, 31}$ And evidence from Clark's own writings disproves his idea that this was harmful to the intellect; when we consider his accounts of the sharp bargaining by the Lower Chinook that he found so distasteful—it is obvious that the intellect of these people was in no way impaired.

So why were Lewis and Clark fairly neutral in their comments regarding these practices in their journals, when it was obvious they considered them barbaric and unsightly? There are two possible answers here. First, the captains knew their journals would be published and widely read, and they felt a need to be the impartial observers the Enlightenment era called for. Vitriolic comments regarding Indian practices were hardly the ideal for a learned and impartial observer of the time, and there is evidence Lewis kept his true feelings in check when he wrote his dispassionate descriptions during the Fort Clatsop winter, a matter which I will discuss below. Second, Clark, in telling Biddle this opinion about the Chinook, is telling us even more about himself. We have seen Clark be more negative towards the Lower Chinook in entries written after his time among them time and again, and this illustrates how his prejudices against these Indians grew. Ronda notes that "the expedition always viewed Indian life

\footnotetext{
${ }^{29}$ Silas B. Smith. "Primitive Customs and Religious Beliefs of the Indians of the Pacific Northwest Coast." Oregon Historical Quarterly 2 (September 1901): 255-56.

31 ibid. 256-57.

${ }^{31}$ Swan. Northwest Coast. 168.
} 
through the filter of its own Euro-American values, ${ }^{, 32}$ and when Clark is critical of coastal Indian customs in his later writings, it tells us what his values were. But there is also something else going on here, and the captains' descriptions of the Lower Chinookan appearance in general will elucidate this for us.

\section{General Chinookan Appearance}

The captains and the enlisted men generally described the physicality and hygiene of the Lower Chinook in negative terms, but there is enough positive description in the journals to give us pause. Lewis is both flattering and scathing in his comments, and while Clark is generally negative, he also leaves us with some positive remarks. The other authors also exhibit both extremes. The comments on appearance and hygiene are inconsiderable enough to include in their entirety, and after summarizing them all, I will discuss why expedition members seem so inconsistent in their remarks on every aspect of Chinookan custom and appearance.

The first group of Lower Chinook encountered by the expedition-the Wahkiakum-is also the first described, naturally enough. On 7 November 1805 Clark describes (in his Field Notes) a visit to a Wahkiakum village in the vicinity of Puget Island. He describes the dress of the women and then the men, and describes the latter as "badly made ..."33 In his Journal Entry the description of native dress is greatly expanded-in fact, it is the "battery of Venus" passage copied from Lewis, and discussed in chapter one-and he also tells us what he meant by his cryptic Field Note

${ }^{32}$ Ronda. Lewis and Clark. 179. 
entry: "those Indians are low and ill Shaped." After leaving these Indians and continuing down the river, the expedition stopped at another Wahkiakum village several miles below, and while Clark doesn't give a description of these natives, Whitehouse does. He writes "the Indians who lived in this small village, where from their appearance a dirty, indolent sett of beings. ${ }^{335}$ Four days later, on the $11^{\text {th }}$, Clark describes the first meeting between the expedition and the Cathlamet Indians. While in his Field Notes he merely writes "those people are badly Clad," in his Journal Entry he adds " $\&$ illy made, Small $\ldots$. ."36

On 19 November, while the expedition was camped at Point Ellice, Whitehouse mentions that "a number of Indians came to visit us at our Camp." He writes "these Indians are a handsome well looking set of People, and were far the lightest colour'd Natives that we had seen since we have been on our Voyage."37 Two days later, Clark records a visit by "several Indians and Squars [who] came this evening ... for the purpose of gratifying the passions of our men ..." And while he once again describes them as "all low both men and women," and says "the men small legs \& thighs and Generally badly made," he also writes "maney of the women are handsom." His Journal Entry again tells us what he means: "the womin of the Chinnook Nation have handsom faces low and badly made with large legs \& thighs ...,", while the men are

\footnotetext{
${ }^{33}$ Moulton. Journals. 6: 30 .

${ }^{34}$ ibid. 32.

${ }^{35}$ ibid.. 11: 389

36 ibid. 6: 40-41.

$3^{-}$ibid. 11: 396.
} 
described as "low homely and badly made, Small Crooked legs large feet, and all of both Sects [sexes] have flattened heads. ${ }^{38}$

Clark comments on the cleanliness of the Clatsops he observed during his 9 December visit to the Clatsop village where he met Cus-ka-lah. In his Journal Entry, he writes "those people appeared much neeter in their diat than Indians Comonly, and frequently wash theer faces and hands." ${ }^{39}$ He next comments on the Indians' appearance on 29 December 1805. In discussing the Lower Chinook in general, he writes in his Field Notes "they are small and not handsom generally Speaking women perticularly." Interestingly enough, he does not add the part about the women being particularly unhandsome in his Journal Entry. ${ }^{40}$

When Lewis resumes his journal, he gives us his view of Chinookan appearance. On 6 January 1806 he writes that "they are generally low in stature, proportionably small, reather lighter complected and much more illy formed than the Indians of the Missouri ..."1 The very next day, on his way to see a beached whale, Clark visited a village of Clatsop Indians located at the mouth of the Necanicum River. In his Field Notes he merely writes "found an old Village of 3 houses, one only inhabited by one familey ..." But in his Journal Entry he tells us "I entered a house where I found a Man 2 Womn \& 3 Children, they appeared retchedly pore \& dirty . ., "42 Two days

\footnotetext{
${ }^{38}$ ibid. 73-76

${ }^{30} \mathrm{ibid} .119$

t) ibid. $143-44$

${ }^{41}$ ibid. 168

42 ibid. 175-77.
} 
later, on his way back to Fort Clatsop, Clark "went into an Indian Lodge" near the salt works, and says "they were dirty and the house full of flees."

The next description of Indians in the journals isn't until 19 March 1806, when Lewis writes that the various tribes in the lower Columbia region

resemble each other as well in their persons and dress as in their habits and manners. - their complexion is not remarkable, being the usual copper brown of most of the tribes of North America. they are low in statue reather diminutive, and illy shapen; possessing thick broad flat feet, thick ankles, crooked legs wide mouths thick lips, noes moderately large, fleshey, wide at the extemity with large nostrils, black eyes and black course hair. their eyes are sometimes of a dark yellowish brown and the puple black. I have observed some high acqualine noses among them but they are extreemly rare. the nose is generally low between the eyes. $^{44}$

Lewis continues in this vein with an impassive description of Lower Chinookan dress and ornamentation, and even describes their personal habits in a fairly positive light when he writes "they are fond of combs and use them when they can obtain them; and even without the aid of the comb keep their hair in better order than many nations who are in other rispects much more civilized than themselves. ${ }^{45}$ But then, after several pages of neutral commentary, he suddenly interrupts his impartial description with a statement that is almost shocking, it is so unexpected: "I think the most disgusting sight I have ever beheld is these dirty naked wenches. ${ }^{, 46}$ Clark copies all of the above nearly

\footnotetext{
43 ibid. 188. The Journal Entry is nearly identical.

${ }^{14}$ ibid. 433

45 ibid.

4h ibid. 436 .
} 
word for word, but he puts a pejorative comment of his own in front of Lewis': "the women Sometimes wash their faces \& hands but Seldom. ${ }^{, 47}$

Such negative statements continue after the party left Fort Clatsop. As the explorers made their way back up the Columbia River, they stopped at a Cathlament village in the vicinity of modern Knappa, Oregon. In his 24 March 1806 entry, Clark writes "the Village of these people is the dirtiest and Stinkingest place I ever Saw and any Shape whatever, and the inhabitants partake of the carrestick [characteristic] of the Village. ${ }^{, 48}$ Ordway writes that the party "remained till $1 / 4$ after 3 p. m. at this village, this is the dirtiest \& Stinkenest place I ever Saw",49 the language of the two entries is so similar that one must have been copied from the other ${ }^{50}$ And Ordway continues his disparaging remarks about the Lower Chinook as they journeyed up the river. When the expedition stopped at the Upper Chinookan village of Cathlapotle at the mouth of the Lewis River, he wrote "this village is more decent than any I have Seen below." Whitehouse echoed this remark, writing " these Indians, are a much decenter looking sett of Natives, than those who reside on, or near the Sea Coast."

\footnotetext{
$4^{-}$ibid. $4+40$.

${ }^{48}$ ibid. 7 : 10 .

${ }^{49}$ ibid. 9: 280

5" Since no other journal writer mentions anything negative regarding this place. it is instructive to look at Clark's and Ordway's entries from the first time the party visited this village, on 26 November 1805. In his Field Notes. Clark does not give any description at all, while in his Journal Entry he writes "this nation appear to differ verry little either in language. Customs dress or appearance from the Chin nooks \& IIar-ci â cum" (Moulton. Journals, 6: 89), leaving us to wonder whether he means this in a positive or negative light. At that earlier date. Ordway writes regarding these same people "they gare us pleanty to eat and appeared verry friendly" (ibid. 9: 257).

${ }^{51}$ ibid. 9: 282 .

52 ibid. 11: 436
} 
Finally, to Biddle, Clark described the Upper Missouri Indian complexion as very similar to that of the frontier Indians Biddle was familiar with. But "on the Westn Side," he says, "the complexion [is] nearly similar the Chopunnish to the Clatsops, tho" these last have a deeper tinge - in general the Fishing nations are somewhat darker than the hunters. ..." And the fishing nations also did not measure up to the lightcomplexioned hunting Indians in another area: "Shoshonees \& Chopunnish wash their faces the fishers dirty \& not wash. ${ }^{, 53}$

There does not seem to be a pattern here. Clark sometimes thinks the women are handsome, and other times does not. In one entry he claims that some of the Lower Chinook wash their hands, and in another even says the Clatsops of Cus-ka-lah's village wash their hands and faces frequently, but then he tells Biddle all natives who live on fish are dirty, and don't wash. Lewis writes that the Indians' complexion on the coast is unremarkable, while Clark tells Biddle they are darker than most Indians, and Whitehouse thinks the Lower Chinook are the lightest colored Indians he has ever seen. Lewis seems inconsistent even within the same entry, when he talks about the Lower Chinook in a tone ranging from neutral to slightly positive, and then suddenly pens the most vitriolic statement written by any member of the expedition about the Lower Chinook during the entire winter. What is going on here?

This inconsistency seems to be another manifestation of what we saw in chapter one of this work, discussing the environment, when the captains encountered an unfamiliar situation that defied description or categorization by any means they were familiar with.

${ }^{53}$ Jackson. Letters. 2: 527 
Just as the environment west of the Rocky Mountains, and especially on the coast, was different than anything they had ever experienced, so the Indians inhabiting that environment were "strange" as well. Lewis and Clark wanted to describe and pigeonhole the various Indian groups they saw, but they could not, because there was such a wide range it seemed that the only rule was that there were exceptions. The Lower Chinook were not universally ugly or dirty, as the accounts from other contemporary visitors, and the inconsistencies in expedition journals, prove. Nor were their practices such as ankle-binding and head deformation crippling or barbaric. But the Indians were different, just as the environment was different, and since the captains could not understand them, they did not like them. 


\section{CHAPTER 7}

\section{Conclusion}

On New Year's Day, 1806, Meriwether Lewis wrote, regarding the climate at the mouth of the Columbia River, "the changes of the weather are exceedingly suddon,", illustrating his frustration with the unpredictable environment of the Pacific Coast. And he could have said much the same about the Indians who lived their lives in that weather. To the white explorers, they were also unpredictable, whether in exchange practices, customs, or appearance. And since the captains could not predict anything about the environment of the Columbia River, or about these Indians living in those surroundings, they did not like anything about the lower Columbia.

The captains' frustrations with the western environment began as soon as Lewis, having eagerly climbed Lemhi Pass, stood gazing westward at the snow-covered peaks that extended as far as he could see. They continued as the party struggled across the rugged Bitterroots and to the end of the nightmarish Lolo Trail, where they finally found the navigable stream they were searching for. And things didn't change after they had built canoes and embarked on their journey down the river: they encountered rapid after dangerous rapid on the Clearwater, Snake, and Columbia rivers. But once they had navigated and portaged the Cascades, there is a note of hopefulness in 
expedition journal entries, as if they feel the worst is surely behind them. On 2 November 1805, the day the party made it through the Cascades, Ordway writes "about 10 oClock A. M. we got all Safe below the last bad rapid we can git any account of from the natives," indicating both relief that the wild water is behind them and assurance the river ahead will be less challenging. ${ }^{2}$ That same day, Clark notes that the river below the Cascades is "wider and bottoms more extencive." More importantly, he notes that at their camp that night, they could see the effects of the tide, a sure sign the ocean could not be much further. ${ }^{3}$ The next day, he continues in like manner, writing that "the Countrey has a handsom appearance," and that there were "no mountains" ahead of them, another indication that they must finally be approaching the coast. When they camped that night, some Indians came into camp and told them they had seen white men in ships at the mouth of the river below, and these natives were kind enough to lend Lewis a small canoe so he could hunt fowl in a large pond in the middle of the island they were camped on. Things were good. The river was broad and calm, the Indians were friendly, and they were near their goal: what could possibly detract from this happy state of affairs? ${ }^{4}$

The next day, 4 November 1805 , reality struck. Some Indians the party had thought were friendly suddenly became "troublesome," and stole Clark's pipe tomahawk, and as the party continued towards the coast, things went rapidly downhill

\footnotetext{
${ }^{1}$ Moulton. Journals. 6: 259.

2 ibid. 9: 248. Whitchouse also records this sentiment: see ibid. 11: 382.

${ }^{3}$ ibid. 6: 7-8.

${ }^{4}$ ibid. 6: $10-12$
} 
in the days, weeks, and months following that incident. The coastal weather was unlike anything the explorers had ever experienced. The Indians were equally unpredictable and untrustworthy, in their eyes. And even unexpected things like fleas tormented the men during their time on the coast. As Lang writes, "the Columbia's environment seemed to put the explorers on edge the farther west they traveled." And the more time they spent in that environment, and among those Indians, the more they seemed to be concerned with what Frederick Turner calls a "fear of becoming possessed, possessed by the wild peoples, yes, but also, more profoundly, by the wilderness and its spirits." The explorers were being overwhelmed by the coastal environment and inhabitants

And their journals reflect this fear, or discomfiture, as we have seen. Complaints about fleas and the weather are frequent and forceful up to the first week in January. But since the explorers could not do anything about the environment, after that time they began concentrating their verbal attacks on the Indians who lived in that environment, and entries written after that time are more extreme in their denunciations of such Chinookan customs and practices as stealing, gift-giving, bartering, and head deformation. But before accepting the implications of these accusations, we need to consider two things. First, we need to recognize that the negative opinions the expedition members had towards the Lower Chinook were largely a reaction against the party's loss of control over their situation west of the Rocky Mountains. After the

"Lang. "Lewis and Clark." 144 
whites crossed over the Continental Divide, virtually every preconception they had about western North America was destroyed, one by one. There was no easy portage. There were vast ranges of lofty mountains, instead of a single, moderately high chain. The river immediately on the western side of the divide was not navigable, and when they finally reached one that was, it still had many dangerous rapids. And when they reached the tidewater, it was not calm and placid, but so turbulent that at times the explorers were trapped on its banks for days. It was only natural that when the whites found the environment so threatening and frightening, they also considered the Indians living in that environment, and their customs, alarming and threatening

And we also need to think about the Chinookan point of view before wholeheartedly accepting the expedition portrayal of them. As Ronda notes, "the expedition always viewed Indian life through the filter of its own Euro-American values," and we need to remember that Indian values were just as legitimate. ${ }^{7}$ Lewis and Clark were visiting their territory, and when the explorers did not conform to local customs, the Indians attempted to force them to through petty theft and harassment. What the whites considered price-gouging, they considered good trade practices. What the explorers thought were distasteful practices were for the Indians the cultural norm. If the whites had attempted to learn, and live by, these norms, the winter would have been more pleasant for both groups.

\footnotetext{
${ }^{6}$ Frederick Turner. Beyond Geography: The Hestern Spirit Against the Hilderness (New York: The Viking Press. 1980). 236.

Ronda. Lewis and Clark. 179.
} 


\section{BIBLIOGRAPHY}

Allen, John Logan. Passage Through the Garden: Lewis and Clark and the Image of the American Northwest. Chicago: University of Illinois Press, 1975.

Ambrose, Stephen E. Undaunted Courage: Meriwether Lewis, Thomas Jefferson, and the Opening of the American West. New York: Simon \& Schuster, 1996.

Bancroft, Hubert Howe. History of the Northwest Coast, 1800-1846. Volume 28 of The Works of Hubert Howe Bancroft. San Francisco: The History Publishers, 1886.

Barry, J. Neilson. "Broughton on the Columbia in 1792." Oregon Historical Quarterly 27 (December 1926): 396-411.

"Columbia River Exploration, 1792." Oregon Historical Quarterly

33 (March 1932): 36-42; (June 1932): 143-55

Boas, Franz. (hinook Texts. Washington, D.C.: Government Printing Office, 1894.

Boyd, Robert. People of the Dalles: The Indians of Wascopam Mission. Lincoln: University of Nebraska Press, 1996.

Cox, Ross. The Columbia River: Or Scenes and Adventures During a Residence of Six Years on the Western Side of the Rocky Mountains Among Various Tribes of Indians Hitherto Unknown; Together With "A Journey Across the American Continent." Edited by Edgar I. Stewart and Jane R. Stewart. Norman, Oklahoma: University of Oklahoma Press, 1957.

DeVoto, Bernard, editor. The Journals of Lewis and Clark. Boston: The Houghton Mifflin Company, 1953

Dunlay, Thomas W. " 'Battery of Venus': A Clue to the Journal-Keeping Methods of Lewis and Clark." We Proceeded on 9 (July 1983): 6-8.

Elliott, T. C. "Captain Robert Gray's First Visit to Oregon." Oregon Historical Quarterly 29 (June 1928): 162-88. 
"Journal of the Ship Ruby." Oregon Historical Quarterly 28 (September 1927): 258-80.

"Log of Captain of H. M. S. Chatham." Oregon Historical Quarterly 18 (December 1917): 239-43.

Franchère, Gabriel. Actventure at Astoria, 1810-1814. Translated by Hoyt C. Franchère. Norman, Oklahoma: University of Oklahoma Press, 1967.

French, David. "Wasco-Wishram." In Perspectives in American Indian Culture Change, edited by Edward H. Spicer, 337-430. Chicago: University of Chicago Press, 1961.

Gibson, James R. "Bostonians and Muscovites on the Northwest Coast, 1788-1841." In The Western Shore: Oregon Country Essays Honoring the American Revolution, edited by Thomas Vaughan, 81-119. Portland, Oregon: Durham \& Downey, 1975 .

Hajda, Yvonne P. "Regional Social Organization in the Greater Lower Columbia, 1792-1830." Ph.D. Diss., University of Washington, 1984

Howay, F. W., editor. "Early Followers of Captain Gray." Washington Historical Quarterly 18 (January 1927): 11-20.

Voyages of the "Columbia" to the Northwest Coast, 1787-1790 and 1790-1793. Boston: The Massachusetts Historical Society, 1941.

"The Resolution on the Oregon Coast, 1793-1794," Oregon Historical (Uarterly 34 (September 1933): 207-15.

Jackson, Donald, editor. Letters of the Lewis and Clark Expedition, With Related Documents 1783-1854. 2 Volumes. Chicago: University of Chicago Press, 1978

Lamar, Howard, and Thompson, Leonard, editors. The Frontier in History: North America and South Africa Compared. New Haven: Yale University Press, 1981

Lang, William L. "Lewis and Clark on the Columbia River: The Power of Landscape in the Exploration Experience." Pacific Northwest Quarterly 87 (Summer 1996): $141-48$ 
Lavender, David. The Way to the Western Sea: Lewis and Clark Across the Continent. New York: Anchor Books, 1988.

Lewis, Albert Buell. "Tribes of the Columbia Valley and the Coast of Washington and Oregon" Memoirs of the American Anthropological Association 1 (19051907): 147-209.

Meany, Edmond S., editor. "New Log of the Columbia by John Boit." Washington Historical Quarterly 12 (January 1921): 3-50.

Miller, Emma Gene. Clatsop County, Oregon: Its History, Legends, and Industries. Portland, Oregon: Binford \& Mort, 1958

Minor, Rick. "Aboriginal Settlement and Subsistence at the Mouth of the Columbia River." Ph.D. Diss., University of Oregon, 1983

Moulton, Gary E., editor. The Journals of the Lewis \& Clark Expedition. 11 Volumes. Lincoln, Nebraska: University of Nebraska Press, 1986-1997.

Olson, Ronald L. "Adze, Canoe, and House Types of the Northwest Coast." University of Washington Publications in Anthropology 2 (November 1927) 3-38

Pryor, Frederic L. The Origins of the Economy: A Comparative Study of Distribution in Primitive and Peasant Economies. San Francisco: Academic Press, 1977.

Ray, Verne F. "Lower Chinook Ethnographic Notes." University of Washington Publications in Anthropology 7 (May 1938): 28-165.

Richardson, Allan. "The Control of Productive Resources on the Northwest Coast of North America." In Resource Managers: North American and Australian Hunter-Gatherers, edited by Nancy M. Williams and Eugene S. Hunn, 93-112. Boulder, Colorado: Westview Press, Inc., 1982

Rickard, T. A. "Drift Iron: A Fortuitous Factor In Primitive Culture." The Geographical Review 24 (October 1934): 525-43

Ronda, James. Lewis and Clark Among the Indians. Lincoln, Nebraska: University of Nebraska Press, 1984.

Ross, Alexander. Adventures of the First Settlers on the Oregon or Columbia River. New York: The Citadel Press, 1969. 
Ruby, Robert H., and Brown, John A. The Chinook Indians: Traders of the Lower Columbia River. Norman, Oklahoma: University of Oklahoma Press, 1976.

Sahlins, Marshall D. "On the Sociology of Primitive Exchange." In The Relevance of Models for Social Anthropology, edited by Michael Banton, 139-236. London Tavistock Publications, 1965.

Smith, Silas B. "Primitive Customs and Religious Beliefs of the Indians of the Pacific Northwest Coast." Oregon Historical Quarterly 2 (September 1901): 255-65.

Stuart, Robert. The Discovery of the Oregon Trail: Robert Stuart's Narratives of His Overland Trip Eastward From Astoria in 1812-13. Edited by Philip Ashton Rollins. Lincoln: University of Nebraska Press, 1995.

Swan, James G. The Northwest Coast, Or, Three Years' Residence in Washington Territory. Seattle: University of Washington Press, 1972.

Turner, Frederick. Beyond Geography: The Western Spirit Against the Wilderness. New York: The Viking Press, 1980.

Thwaites, Rueben Gold, editor. Original Journal of the Lewis and Clark Expedition 1804-1806. Volume 3. New York: Arno Press, 1969.

Vancouver, George. A Voyage of Discovery to the North Pacific Ocean and Round the World 1791-1795. W. Kaye Lamb, editor. 4 Volumes. London: The Hakluyt Society, 1984.

Vaughan, Thomas. "River of the West." American History Illustrated 27 (May/June 1992): $28-43$

Wagner, Henry R. "The Last Spanish Exploration of the Northwest Coast and the Attempt to Colonize Bodega Bay." California Historical Quarterly 10 (December 1931): 313-45. 